\title{
Progress Report on Daily Flow-Routing Simulation for the Carson River, California and Nevada
}

By GLEN W. HESS

U.S. GEOLOGICAL SURVEY

Open-File Report 96-211

A product of the

Truckee-Carson Program

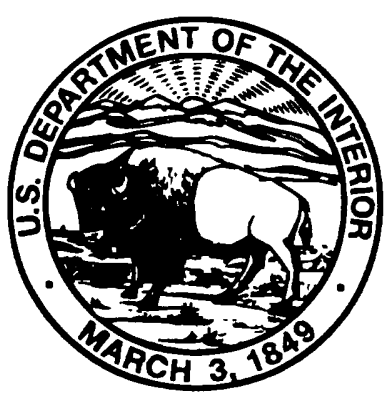

Carson City, Nevada 1996 


\title{
U.S. DEPARTMENT OF THE INTERIOR BRUCE BABBITT, Secretary
}

\author{
U.S. GEOLOGICAL SURVEY \\ GORDON P. EATON, Director
}

Any use of trade names in this publication is for descriptive purposes

only and does not constitute endorsement by the U.S. Government

For additional information write to:

District Chief U.S. Geological Survey 333 West Nye Lane, Room 203 Carson City, NV 89706-0866
Copies of this report can be purchased from:

U.S. Geological Survey

Information Services

Box 25286, MS 517

Denver Federal Center

Denver, CO 80225-0046 


\section{CONTENTS}

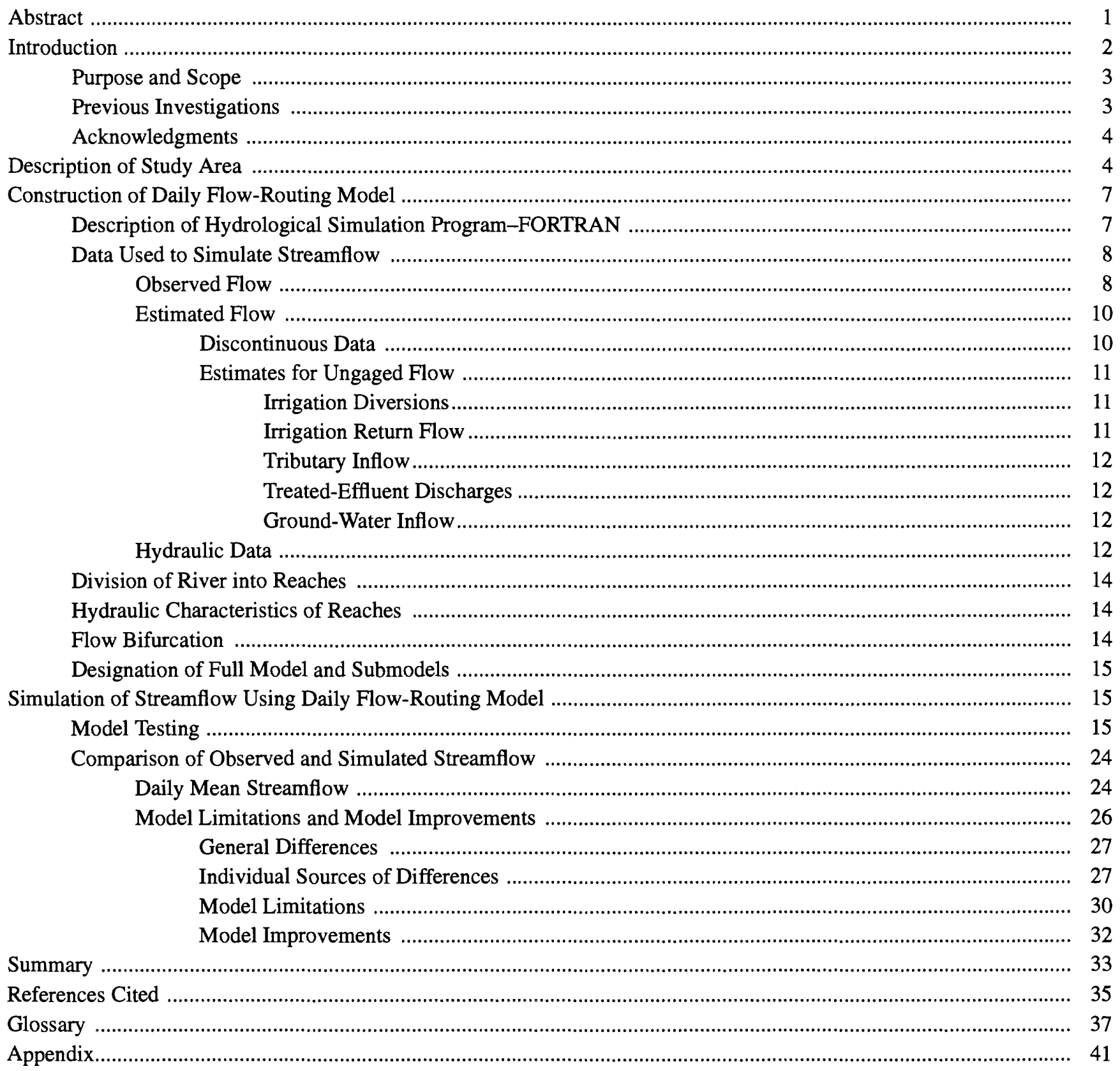




\section{PLATE}

1. Map showing hydrologic features, data-collection network, and reaches of the Carson River, eastern California and western Nevada.

\section{FIGURES}

1. Map showing hydrologic features of Carson and Truckee River Basins and adjacent areas, eastern

California and western Nevada

2. Hydrographs showing observed and simulated daily mean streamflow, April 1-22, 1984, full model:

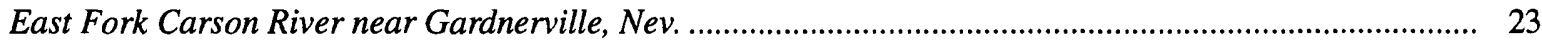

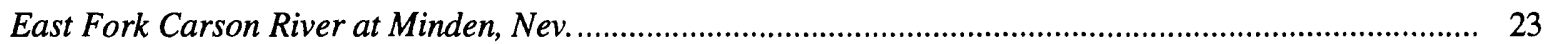

Carson River near Carson City, Nev................................................................................................. 23

Carson River at Deer Run Road near Carson City, Nev.....................................................................2. 23

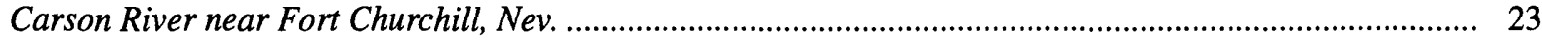

3-7. Hydrographs showing observed and simulated daily mean streamflow:

3. Carson River near Carson City, Nev., February 1986, full model........................................................... 24

4. East Fork Carson River near Gardnerville, Nev., January through December 1980, full model................. 26

5. Carson River near Carson City, Nev., July through September 1992, full model ........................................ 26

6. East Fork Carson River near Gardnerville, Nev., January through December 1990, full model.................. 28

7. Carson River near Fort Churchill, Nev., January through December 1991, full model............................. 29.

\section{TABLES}

1. Data-collection sites used for constructing Carson River flow-routing models, California and Nevada

2. Selected reach characteristics of East Fork Carson River, West Fork Carson River, Brockliss Slough, and mainstem Carson River used to describe hydraulic properties and ground-water outflow in the flow-routing models

3. Carson River model reaches and Alpine Decree segments for the full model and submodels. 16

4. Carson River model reach inflows and outflows

5. Measures of differences between observed and simulated daily mean streamflow for gaging stations used in model testing.....

6. Sensitivity of simulated daily mean streamflow to changes in time-series data for four components of hydrologic system estimated for flow-routing models....

\section{CONVERSION FACTORS AND VERTICAL DATUM}

\begin{tabular}{rll}
\hline Multiply & By & To obtain \\
\hline acre-foot $(\mathrm{acre}-\mathrm{ft})$ & 1,233 & cubic meter \\
cubic foot per second $\left(\mathrm{ft}^{3} / \mathrm{s}\right)$ & 0.02832 & cubic meter per second \\
foot $(\mathrm{ft})$ & 0.3048 & meter \\
mile $(\mathrm{mi})$ & 1.609 & kilometer \\
\hline
\end{tabular}

Temperature: Degrees Celsius $\left({ }^{\circ} \mathrm{C}\right)$ can be converted to degrees Fahrenheit $\left({ }^{\circ} \mathrm{F}\right)$ by using the formula ${ }^{\circ} \mathrm{F}=\left[1.8\left({ }^{\circ} \mathrm{C}\right)\right]+32$. Degrees Fal $-e n h e i t$ can be converted to degrees Celsius by using the formula ${ }^{\circ} \mathrm{C}=0.556\left({ }^{\circ} \mathrm{F}-32\right)$.

Sea level: In this report, "sea level" refers to the National Geodetic Vertical Datum of 1929 (NGVD of 1929, formerly called "Sea-Level Datum of 1929"), which is derived from a general adjustment of the first-order leveling networks of the United States and Canada. 


\title{
Progress Report on Daily-Flow Routing Simulation for the Carson River, California and Nevada
}

\author{
By Glen W. Hess
}

\section{Abstract}

A physically based flow-routing model using Hydrological Simulation ProgramFORTRAN (HSPF) was constructed for modeling streamflow in the Carson River at daily time intervals as part of the Truckee-Carson Program of the U.S. Geological Survey (USGS). Daily streamflow data for water years 1978-92 for the mainstem river, tributaries, and irrigation ditches from the East Fork Carson River near Markleeville and West Fork Carson River at Woodfords down to the mainstem Carson River at Fort Churchill upstream from Lahontan Reservoir were obtained from several agencies and were compiled into a comprehensive data base. No previous physically based flow-routing model of the Carson River has incorporated multi-agency streamflow data into a single data base and simulated flow at a daily time interval. Where streamflow data were unavailable or incomplete, hydrologic techniques were used to estimate some flows. For modeling purposes, the Carson River was divided into six segments, which correspond to those used in the Alpine Decree that governs water rights along the river. Hydraulic characteristics were defined for 48 individual stream reaches based on crosssectional survey data obtained from field surveys and previous studies.

Simulation results from the model were compared with available observed and estimated streamflow data. Model testing demonstrated that hydraulic characteristics of the Carson River are adequately represented in the models for a range of flow regimes. Differences between simulated and observed streamflow result mostly from inadequate data characterizing inflow and outflow from the river. Because irrigation return flows are largely unknown, irrigation return flow percentages were used as a calibration parameter to minimize differences between observed and simulated streamflows. Observed and simulated streamflow were compared for daily periods for the full moteled length of the Carson River and for two major subreaches modeled with more detailed input data. Hydrographs and statistics presented in this repct describe these differences.

For daily mean streamflow, the full-model and submodel simulations near the Minden and Carson City gaging stations were about the same. At gaging stations farther downstream, however, the streamflow simulations by the submodel were more accurate than those by the full model. This discrepancy is because in the full model, differences between observed and simulated streamflow accumulate as the model routes flow downstream. A sensitivity analysis of four estimated components of the hydrologic system evaluated which components were significant in the model. Estimated ungaged tributary streamflow is not a significant component of the model during low runoff, but is significant during higk runoff. The sensitivity analysis indicates that changes in the estimated irrigation diversion and estimated return flow creates a noticeable change in the statistics. The sensitivity analysis indicates that when using a simple constant estimate of ground-water inflow, it's contribution is not a significant component of the model. 
The modeling for this study is preliminary. Results of the model are constrained by current availability and accuracy of observed hydrologic data. Several inflows and outflows of the Carson River are not described by time-series data and therefore are not represented in the model. Additional gaging stations recording flow from the major tributaries, diversions, and return flows, as well as more sites along the Carson River would provide additional information for testing the current model and for future modifications to better define components of the hydrologic system.

\section{INTRODUCTION}

Water-related conflicts are long-standing among various economic, political, ecological, and institutional interests in the Truckee and Carson River Basins in eastern California and western Nevada. The diversity of these interests creates a wide range of competing alternatives for planning, allocating, and managing the water resources and for operating the various reservoirs and diversion systems. The Carson River, shared between California and Nevada, has been involved in one of the longest running Federal District Court Water-Rights cases in the nation-a 55-year suit that led to the Alpine Decree (U.S. District Court, 1980); this decree adjudicates most of the surfacewater rights on the upper Carson River.

The Truckee River, also shared between California and Nevada, has had a similar history of public controversy over water-rights distribution. Negotiations among various interest groups finally resulted in the Truckee River Agreement (U.S. Department of Interior, 1935), which established the basis for operation of the Truckee River, Lake Tahoe, storage in downstream lakes and reservoirs, and flow on the Truckee River. The Truckee River Agreement became an important element in the Orr Ditch Decree (U.S. District Court, 1944); this decree confirms individual water rights held for the Newlands Project, one of the first Federal irrigation projects (California Department of Water Resources, 1991, p. 11). Together, the Orr Ditch Decree and Truckee River Agreement govern the interbasin transfer of Truckee River streamflow diverted through the Truckee Canal into Lahontan Reservoir in the Carson River Basin.
Public Law 101-618, the Truckee-CarsonPyramid Lake Water Rights Settlement Act (199?), was legislated to develop operating criteria to budget interstate allocation and for water demands for municipal use, irrigation, fish and wildlife, and recreation, as well as to meet water-quality criteria for these uses. Many of the planning, management, or environmentalassessment requirements of the Act require detailed understanding of the hydrologic system. Existing data networks and interbasin modeling tools do not provide enough quantitative detail to address the broad s nectrum of water-resources issues in the two basins for Public Law 101-618, particularly for documenting the short- and long-term variability in water supply in these basins. A physically based computer mcdel capable of simulating flow at a daily time interval would help in assessing alternatives for water allocation and management, such as allocation of streamflow and maintenance of instream water-quality standards, particularly if the model is interbasin in scope. The computer model presented in this report includes a data-management and flow-routing system and is a part of a modular-framework modeling system that is structured to allow integration of new and more refined and detailed hydrologic-analysis tools. This framework provides standard formats for data exchange and for graphical and statistical summaries. In addition to flow-routing data, information on water quality, operations and allocations, and precipitation run fff can be built into this modular framework in a stepwise fashion.

The Truckee-Carson Program of the U.S. Geological Survey (USGS) was established by the Department of Interior to support implementation of Public Law 101-618 by (1) compiling records from multi-agency gaging stations into a consistent longterm data base to provide reliable data in support of modeling activities in the Truckee and Carson River Basins, and (2) developing a modular-framewor" modeling system. Modeling activities in this second element for the USGS Truckee-Carson Program: include the following potential study elements:

- Develop and apply a general model for the Truckee and Carson Rivers, and the Trurkee Canal, including physically based flow routing, water operations, and precipitationrunoff on a daily time interval. 
- Add modules that will incorporate temperature and river-water-quality data to evaluate effects of water-management alternatives on Truckee River water quality, especially in the lower river reach from Reno to Pyramid Lake. Also select key subbasins from which to develop models representing ground-water/surfacewater interactions.

This progress report describes development and application of a physically based flow-routing model (a part of the first element) that can simulate daily flows for a part of the Carson River Basin. A companion report by Berris (in press) describes simulation of daily streamflow using a flow-routing model for the Truckee River.

\section{Purpose and Scope}

The purpose of this progress report is (1) to describe the data, including a description of the methods used to estimate ungaged flows, and reach segmentation used in the construction of a daily flow-routing model that incorporates hydraulic characteristics of the Carson River, (2) to test the hydrologic and hydraulic characterization of the Carson River, (3) to compare observed and simulated streamflow, and (4) to discuss the differences between observed and simulated streamflows and the limitations of the model.

Streamflow is modeled for water years 1978-92 (October 1, 1977, to September 30, 1992) from the gaging stations East Fork Carson River near Markleeville, Calif., and West Fork Carson River at Woodfords, Calif., to the gaging station Carson River at Fort Churchill, Nev., just upstream from Lahontan Reservoir. This study is considered preliminary; the model can be updated once additional data and information are available that address components of the hydrologic system that were estimated for this study.

\section{Previous Investigations}

Several investigators have determined the annual water budget of the Carson River Basin. Piper (1969) investigated the water budget of Carson Valley, which is part of the Carson River Basin, and noted mean yearly runoff depending on altitude and location in the basin. Piper also estimated mean yearly consumptive use of water by irrigation. A water-resources appraisal of the Carson River Basin by Glancy and Katzer (1975) determined quantitative hydrologic estimates, such as average annual inflow, outflow, water imported from the Truckee Canal, natural evapotranspiration, and ground-water supply. A similar study of Eagle Valle; in the Carson River Basin by Worts and Malmberg (1966) estimated the annual yield from surface-water and ground-water sources. The USGS compiled climate, water-use, and hydrologic data to assess watequality for different seasons and locations along the Truckee and Carson Rivers (Nowlin and others, 1980; Brown and others, 1986). These reports and their plates are a source of comprehensive information about the Carson and Truckee Rivers.

A numerical model simulating ground-water storage in Carson Valley was developed by Maurer (1986), and Maurer and Peltz (1994) to characterize the hydrologic system. Mauer mapped geologic components of the basin-fill aquifer and the distribution of aquifer materials. The model estimated how these factors affect hydraulic properties and water-budget components throughout the valley. The steady-state simulation showed net average annual losses due to surface-water percolation, evapotranspiration, and evaporation.

An interagency team reviewed two models of the Truckee and Carson River Basins by Cobb and others (1990): the Bureau of Reclamation Model and the Negotiations Model. The models simulate streamflow at monthly intervals using mass-budget accourting, as opposed to physically based flow routing. Tr o models were constructed from a long-term (1901-80) data base of monthly synthesized streamflows and were used to compare effects of alternative management practices on streamflow. These two uncalibrated models focused on the Truckee River system; to a lesser degree, the Truckee Canal and the Carson River from Churchill Valley to Lahontan Valley also were modeled. Model results for the Truckee Canal and Lahontan Valley were compared for several scenarios of water demands and depletions to determine what shortages might result in the Newlands Project area.

Kennedy/Jenks Consultants (1991) used the MODSIM river model to simulate monthly streamflow along Nevada segments of the upper Carson River- 
defined in the Alpine Decree (U.S. District Court, 1980). MODSIM is a water-management model that takes into account the decreed water-rights priority system. Observed streamflow at gaging stations at the segment boundaries was compared to simulated flow. Reservoir operations, irrigation return flow, groundwater interactions, and undecreed irrigation practices were not included in this analysis, nor were model results statistically compared.

Several studies in recent years have looked at how changes in climate might affect streamflow in the mountainous areas of the upper Carson River. Annual and monthly streamflow records for 1939-90 on the West Fork Carson River were analyzed for evidence of changes in runoff characteristics (Pupacko, 1993). Increased winter and early spring streamflow during water years 1965-90 was attributed to small increases in mean monthly minimum temperature causing earlier snowmelt at the higher altitudes. Other studies are based on the models of global climate change. Duell (1992) used regression models to estimate effects of climate on seasonal streamflow for water years 1951-90 for a number of eastern and western Sierra Nevada basins. In these models, temperature and precipitation were varied, and precipitation was found to be the most statistically significant variable in the high altitudes of the Carson River Basin. The USGS Precipitation-Runoff Modeling System (a physically based, distributed-parameter watershed model) simulated daily runoff in the East Fork Carson River for water years 1969-90 (Jeton and Smith, 1993). The model used a geographic information system to subdivide the basin into hydrologically homogeneous areas for modeling runoff (Smith and Reece, 1995).

\section{Acknowledgments}

The author gratefully acknowledges the support of many people and agencies who provided data used in this report: the U.S. District Court Water Master; Gene Eppler of South Tahoe Public Utility District; Gary Hoffman of Carson City Wastewater Treatment Plant; Carol Grenier, Al Olson, and Chuck Vincent of Bureau of Reclamation; the Douglas County Sewer Improvement District; the Incline Village General Improvement District; and the Nevada Department of Environmental Protection. Additional cross-sectional data were provided by the U.S. Department of the Army, Corps of Engineers; Bureau of Reclamation;
Federal Emergency Management Agency; and Nimbus Engineers. Douglas County and U.S. Department of the Army, Corps of Engineers (Sacramento District) provided aerial mapping of Douglas County. Several people in the office of the U.S. District Court Water Master, notably Garry D. Stone, Jeff Boyer, Julian Larrouy, and Ed Mees, provided insight into the complexities and operation of the Carson River Basin.

\section{DESCRIPTION OF STUDY AREA}

From its headwaters in Alpine County, Calif., the Carson River flows to the northeast through Carson Valley, parts of Carson City, Dayton Valley, and Churchill Valley into Lahontan Reservoir. From that reservoir, the regulated lower river continues northeastward through the Newlands Project in Lahortan Valley and ultimately terminates in the Carson Sink (fig. 1 and pl. 1). The waters of the Carson River and its tributaries support a variety of uses-providing municipal water supply, sustaining fish and wildlife habitat, generating hydroelectric power, furnishing river and reservoir recreational opportunities, and serving agriculture.

The mean annual minimum and maximum temperatures are 2 and $17^{\circ} \mathrm{C}$ at Woodfords, Calif. On average, 80 percent of the annual precipitation falls from November to March-mostly as snow. Winter precipitation in the Carson River Basin is stored mostly as snowpack and runoff occurs later in spring.

The upper watershed of the Carson River is in Alpine County, Calif., and is divided into two parts--the West Fork Carson River and East Fork Carson River (hereafter referred to as West Fork and East Fork) - both of which arise in the Sierra Nevada. Highest headwater altitudes are at about $9,000 \mathrm{ft}$ above sea level on the West Fork and $11,000 \mathrm{ft}$ on the East Fork (California Department of Water Resources, 1991, p. 5). A characteristic shared by both forks of the river at the higher altitudes is the steep slopes of their channels; most runoff in the watershed is from th: eastern slopes of the Sierra Nevada where precipitatinn, mostly as snowfall, is greatest. Another shared characteristic is the number of small natural lakes at higher altitudes. Some of the lakes have been converted to reservoirs by constructing small dams at the outlets; the capacity for water storage in these reservoirs is small. 


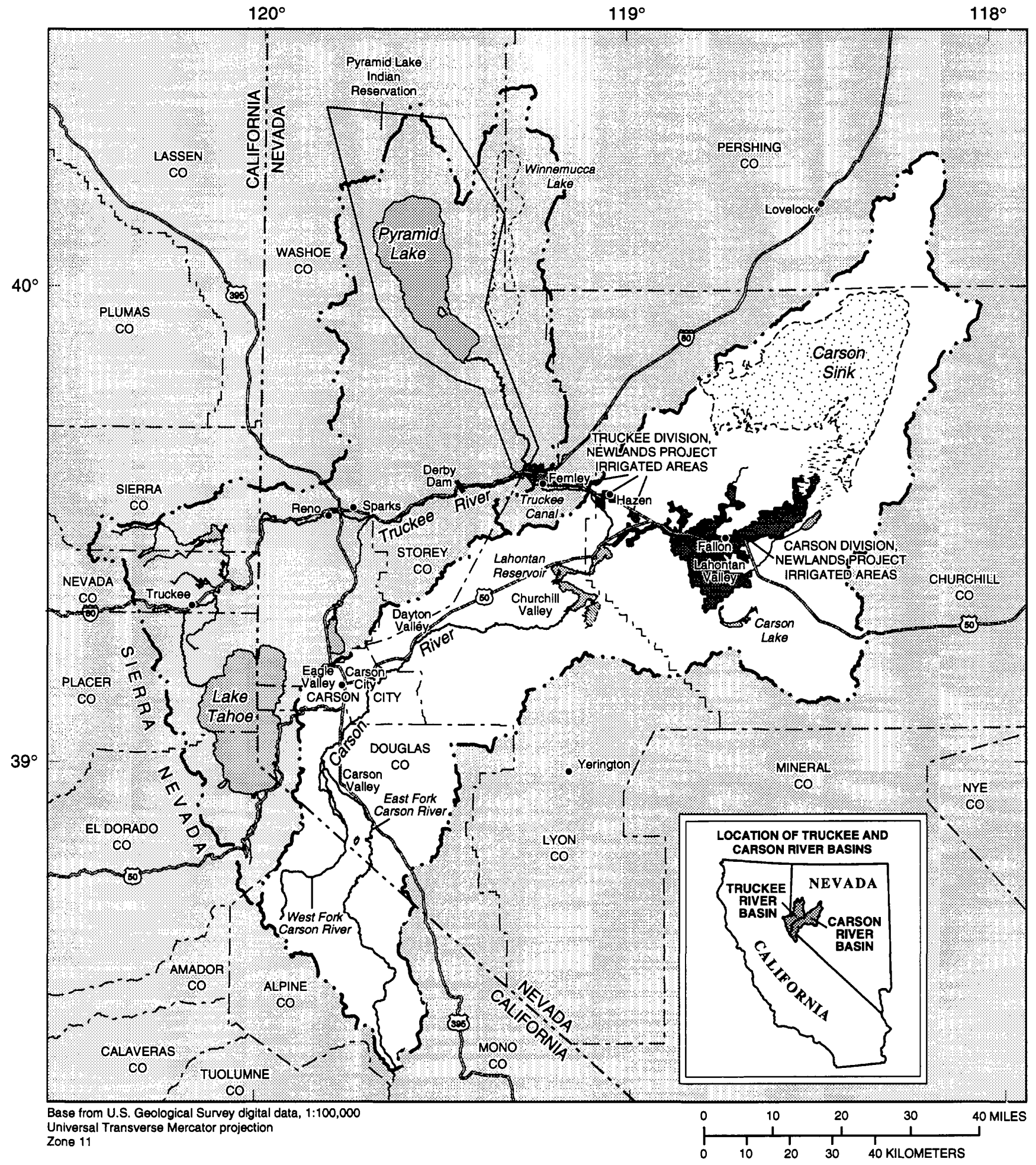

EXPLANATION

Hydrographlc boundary

Figure 1. Hydrologic features of the Carson and Truckee River Basins and adjacent areas, eastern California and western Nevada. 
West Fork streamflow upstream from the small town of Woodfords is only slightly regulated by reservoirs (total capacity approximately 2,000 acre-ft), and the amount of diversion upstream from Woodfords is negligible (California Department of Water Resources, 1991, p. 5). The only agricultural area in the upper watershed is in Diamond Valley directly downstream from Woodfords where a canal-and-ditch system distributes irrigation water. Between the West Fork and East Fork Carson Rivers is Mud Lake, a 3,100-acre-ft-capacity reservoir fed mostly by Indian Creek (pl. 1), which can be used to store municipal water for Carson City. The West Fork continues northeastward before entering Carson Valley.

On the East Fork, streamflow upstream from Markleeville, Calif., also is only slightly regulated by several small reservoirs (total capacity approximately 5,000 acre-ft; California Department of Water Resources, 1991, p. 7). This fork veers to the northeast at the town of Markleeville and crosses into Nevada just upstream of the confluence with Bryant Creek. The East Fork continues through a narrow canyon and enters into the Carson Valley near Gardnerville.

The West and East Forks of the Carson River join in the broad Carson Valley in Nevada where the average altitude is approximately $4,700 \mathrm{ft}$. Although Carson Valley historically has been largely agricultural, recently suburban development is increasing in and near the towns of Minden and Gardnerville. The intricate canal-and-ditch systems that begin in the Diamond Valley area in California also serve water users in the Carson Valley and are responsible for the lush green fields in an otherwise high-desert terrain. The Carson Valley is still the major agricultural area of the upper Carson River and is characterized hydrologically by a complex system of channels, small reservoirs, diversions, and return flows (pl. 1). From the 1850 's through the early 1900 's, ranching interests developed a series of small upstream reservoirs to store water, and a canal system to distribute it across the Carson Valley (Dangberg, 1975, p. 11). This system exists today, much as it was originally developed, in an area of approximately 43,000 acres of decreed farmland (U.S. District Court, 1980). On entering the Carson Valley, most of the flow of the East Fork is diverted for irrigation. Irrigation diversions on the western side of the East Fork flow toward the West Fork, leaving little flow in the East Fork during dry years. The West Fork is regulated from the first
Monday in June until October 1 on the basis of the Alpine Decree. Diversions are altered weekly; land in California is irrigated one week and land in Nevada is irrigated the next. The West Fork bifurcates near Dresslerville into the West Fork and Brockliss Slough, and most of the flows go down the Brockliss Sloigh; the West Fork serves primarily as a catchment fcr irrigation return flow from the western side of the East Fork. The East Fork, West Fork, and Brockliss Slough combine near Genoa, Nev., to form the mainstem Carson River.

The mainstem Carson River flows along th? eastern edge of Eagle Valley through parts of Carson City before cutting east through Brunswick Canyon. Many mills in the Comstock Lode era (1856-81) processed gold and silver ore in this canyon using river water. A legacy of the Comstock Lode is mercury, a by-product of the milling processes, that still remains in the Carson River downstream from Carson City (Van Denburgh, 1973, p. 2). Legal battles between agricultural and milling interests in the 1800's are described by Dangberg (1975). The Carson Rive" then enters a small valley near the town of Dayton. Downstream from Dayton, the river passes through another agricultural area in Churchill Valley and another short canyon before going east toward Fort Churchill and into Lahontan Reservoir (capacity 314,000 acre-ft; U.S. Geological Survey, 1993, p. 197), the only large reservoir on the Carson River.

Lahontan Reservoir stores the flow of the Carson River below Fort Churchill, as well as water imforted from the Truckee River via the Truckee Canal. Inflow to Lahontan Reservoir is assumed to be the same as the flow passing the Fort Churchill area (Cobb and others, 1990, p. 14; Clyde-Criddle-Woodward, Inc., 1971, p. 22). Inflow to Lahontan Reservoir from the Tr'ckee Canal consists of water diverted at Derby Dam into the canal minus spills, seepage losses, and deliveries to the Truckee Division laterals along the Truckee Canal. Water released from Lahontan Reservoir into the river either flows through or bypasses Lahontan Power Plant at the base of Lahontan Dam. Water practices af $r$ the construction of the Newlands Project also included pumping water from Lahontan Reservoir upstresm through the Truckee Canal to serve a part of the Truckee Division; however, this pumping ceased sometime in the 1930's (Townley, 1977, p. 53). 


\section{CONSTRUCTION OF DAILY FLOW-ROUTING MODEL}

The Hydrological Simulation ProgramFORTRAN (HSPF) (Bicknell and others, 1993) was used to construct the flow-routing model of the mainstem Carson River from daily streamflow data for water years 1978-92. The following sections describe (1) the HSPF model, (2) data used to simulate streamflow, (3) division of the river into six segments (as in the Alpine Decree) and 48 reaches, (4) hydraulic characteristics of the 48 reaches, and (5) construction of the full model and two submodels.

\section{Description of Hydrological Simulation Program-FORTRAN}

The hydrologic and hydraulic model HSPF, developed by Bicknell and others (1993), contains several optional, versatile modules for hydrologic simulations. It was chosen for the Carson River flowrouting model primarily because it can (1) simulate streamflow continuously over different flow regimes, including periods of storm runoff and low flows; (2) depict flow at hourly, daily, monthly, and annual intervals; (3) incorporate the hydraulics of complex natural and constructed drainage networks; (4) account for both inflow and diversions; and (5) simulate flow at a large number of sites. HSPF modules can simulate physical hydrologic processes, such as flow routing or precipitation-runoff, as well as associated waterquality processes on the land surface, in streams, in well mixed impoundments, and in subsurface aquifers. The following sections describe the data-management system ANNIE and the flow-routing modules used in this study. The precipitation-runoff part of HSPF was not used. Precipitation-runoff in the basin will be studied in a later phase of the project.

ANNIE is a time-series, data-management system (Lumb and others, 1990) that includes file creation and data management, analysis, and display. ANNIE is used to manage the daily time-series data describing each component of the hydrologic system in the Carson River Basin. Individual HSPF modules take the ANNIE time-series data files as input and are capable of writing files as output to be stored in the ANNIE data base.
The HSPF "blocks" used in the flow-routing module in this study are HYDR, RCHRES, and FTABLE. The information the user must provide to run HSPF is in the user's control input (UCI). The UCI provides instructions to HSPF by defining where a module's input and output commands are stored. Instructions for additional modules describing physical processes may be added to the UCI.

The block in HSPF that can simulate unsteady flow, HYDR, is capable of simulating flow through the complex systems of channels, reservoirs, and irrigation diversions and returns found in the study area. HYC ${ }^{\text {? }}$ represents physical processes of flow by treating stretches of the river, or reaches, as a series of linked (but not necessarily linear) reservoirs. (A reach is a s $n$ gle zone between two points along a river.) Inflow to and outflow from a reach may be either simulated b:" HSPF or, in the case of this study, provided to HSPF as actual time-series data, such as streamflow measured at gaging stations. The outflow from one reach is then routed to the next downstream reach by using a modified kinematic-wave or storage-routing algorithm. Any water-conveyance system with known and unchanging hydraulic characteristics may be included in the flor" network; this includes all mainstem streams, tributaries, lakes and reservoirs, and irrigation canals, ditches, and drains-as long as variable backwater conditions or pressurized flow do not normally occur.

The RCHRES block in HSPF simulates processes within a single reach. Flow through a reach is assumed to be unidirectional--the water flows downstream only. Mainstem flow and additioral sources, such as tributary and irrigation return flow, enter a reach from defined inlets. Precipitation, evar?ration, and other fluxes may affect the processes with in a reach. Outflow in the model, such as irrigation diversions or ground-water losses, may leave a reach through a total of five defined outlets. RCHRES routes the streamflow by performing a water-budget analysis that accounts for all inflow to, outflow from, and volume of water stored in each reach for a given time interval. HSPF stores cross-sectional data and chanrel geometry representing hydraulic properties of a river reach in the FTABLE block. An FTABLE specifies a fixed relationship between depth, surface area, volume, and discharge for each river reach. In summary, inflcw and outflow data for the flow-routing module determine the volume of streamflow simulated by the model in RCHRES, whereas reach length and hydraulic 
characteristics in FTABLE determine the timing and affect of flows and how that volume is routed from an upstream reach to a downstream reach in the HYDR.

\section{Data Used to Simulate Streamflow}

The model simulations of Carson River flow are based on time-series data describing inflow to and diversions from the river. Time series of observed daily streamflow data were compiled from several agencies into a comprehensive ANNIE data base to construct the flow-routing model for the Carson River Basin. (In this report, the term observed data refers to the data base generated from continuous or intermittent gagingstation data.) Some of the gaging-station records used in this study and other hydrologic and climatic data bases are listed by August and others (1992). If time series of streamflow data were unavailable, hydrologic techniques were used to estimate them. Cross-sectional survey data used to determine hydraulic characte-istics of the reaches were assembled from several sour ses or were collected in field surveys for areas where no data were available.

\section{Observed Flow}

The data base compiled to construct and test the model includes streamflow data for mainstern streams, tributaries, and irrigation ditches for witer years 1978-92 (for sites, see pl. 1 and table 1); th is is the same period used by Berris (in press) to simulate streamflow in the Truckee River. This 15-year period was chosen because streamflow data were collected at more gaging stations than in previous years. $f$ dditionally, this period includes a wide range of water discharges in the Carson River allowing the model accuracy to be tested for higher and lower flow periods.

Table 1. Data-collection sites used for constructing Carson River flow-routing models

[Agency source: CCWTP, Carson City Wastewater Treatment Plant; DCSID, Douglas County Sewer Improvement District; FWM, U.S. District Cou t Water Master or Federal Water Master; IVGID, Incline Village General Improvement District; MGSD, Minden-Gardnerville Sanitation District; STPUD, South Tahoe Public Utilities District; USGS, U.S. Geological Survey]

\begin{tabular}{|c|c|c|c|c|}
\hline $\begin{array}{c}\text { Site } \\
\text { no. } \\
\text { (pl. 1) }\end{array}$ & Agency source & Station no. & Station name & 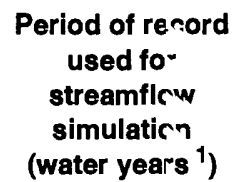 \\
\hline 1 & USGS & 10308200 & East Fork Carson River near Markleeville, Calif. & 1978-92 \\
\hline 2 & USGS & 10308800 & Bryant Creek near Gardnerville, Nev. & $1978-80,1981-82$ \\
\hline 3 & USGS & 10309000 & East Fork Carson River near Gardnerville, Nev. & $1978-92$ \\
\hline 4 & FWM & $\mathrm{C} 82$ & Allerman Canal near Dresslerville, Nev. & 1984-92 \\
\hline 5 & USGS & 10309025 & Indian Creek near Woodfords, Calif. & $1987-8$ ? \\
\hline 6 & USGS & 10309030 & Indian Creek near Paynesville, Calif. & $1987-89$ \\
\hline 7 & FWM & C84 & Rocky Slough at Dresslerville, Nev. & $1982-92$ \\
\hline 8 & FWM & $\mathrm{C} 85$ & Edna Ditch near Dresslerville, Nev. & $1982-92$ \\
\hline 9 & FWM & C83 & Virginia Ditch at Dresslerville, Nev. & $1983-92$ \\
\hline 10 & USGS & 10309050 & Pine Nut Creek near Gardnerville, Nev. & $1980-92$ \\
\hline 11 & FWM & $\mathrm{C} 86$ & Company Ditch near Gardnerville, Nev. & 1984-92 \\
\hline 12 & FWM & $\mathrm{C} 88$ & Henningson Ditch near Gardnerville, Nev. & $1983-92$ \\
\hline 13 & FWM & $\mathrm{C} 87$ & Cottonwood Slough near Gardnerville, Nev. & $1983-92$ \\
\hline 14 & MGSD & 385814119475101 & $\begin{array}{l}\text { Minden-Gardnerville Sanitation District effluent near } \\
\text { Gardnerville, Nev. }\end{array}$ & $1978-86$ \\
\hline 15 & USGS & 10309070 & Buckeye Creek near Minden, Nev. & $1980-92$ \\
\hline
\end{tabular}


Table 1. Data-collection sites used for constructing Carson River flow-routing models-Continued

\begin{tabular}{|c|c|c|c|c|}
\hline $\begin{array}{l}\text { Site } \\
\text { no. } \\
\text { (pl.1) }\end{array}$ & Agency source & Station no. & Station name & $\begin{array}{l}\text { Period of recor }-1 \\
\text { used for } \\
\text { streamflow } \\
\text { simulation } \\
\text { (water years }{ }^{1} \text { ) }\end{array}$ \\
\hline 16 & USGS & 10309100 & East Fork Carson River at Minden, Nev. & $1978-84$ \\
\hline 17 & DCSID & 385815119475401 & $\begin{array}{l}\text { Douglas County Sewer Improvement District } \\
\text { effluent discharge near Minden, Nev. }\end{array}$ & 1978-79 \\
\hline 18 & FWM & C89 & Hayburn Ditch near Minden, Nev. & $1983-92$ \\
\hline 19 & USGS & 10310000 & West Fork Carson River at Woodfords, Calif. & $1978-92$ \\
\hline 20 & FWM & C76 & Snowshoe Thompson No. 1 Ditch near Woodfords, Calif. & $1984-92$ \\
\hline 21 & FWM & $\mathrm{C} 77$ & West Fork Carson River at Paynesville, Calif. & $1982-92$ \\
\hline 22 & STPUD & 38450811946280 & $\begin{array}{l}\text { South Tahoe Public Utility District effluent discharge from } \\
\text { Indian Creek Reservoir near Paynesville, Calif. }\end{array}$ & $1981-92$ \\
\hline 23 & FWM & C78 & Fredericksburg Ditch near Paynesville, Calif. & $1982-92$ \\
\hline 24 & USGS & 10310300 & Fredericksburg Canyon Creek near Fredericksburg, Calif. & $1988-92$ \\
\hline 25 & FWM & C79 & $\begin{array}{l}\text { West Fork Carson River at Dressler Lane near } \\
\text { Fredericksburg, Calif. }\end{array}$ & $1982-92$ \\
\hline 26 & FWM & $\mathrm{C} 80$ & Brockliss Slough at Ruhenstroth Dam near Gardnerville, Nev. & $1982-92$ \\
\hline 27 & FWM & C81 & Brockliss Slough at Scossa Box near Gardnerville, Nev. & $1982-92$ \\
\hline 28 & USGS & 10310400 & Daggett Creek near Genoa, Nev. & $1978-84,1988-\Omega_{2}$ \\
\hline 29 & USGS & 10310405 & Carson River at Genoa, Nev. & $1978-81$ \\
\hline 30 & IVGID & 390426119460401 & $\begin{array}{l}\text { Incline Village General Improvement District treatment } \\
\text { plant effluent discharge near Carson City, Nev. }\end{array}$ & $1978-85$ \\
\hline 31 & USGS & 10310500 & Clear Creek near Carson City, Nev. & 1989-92 \\
\hline 32 & USGS & 10311000 & Carson River near Carson City, Nev. & $1978-92$ \\
\hline 33 & FWM & C61 & Mexican Ditch near Carson City, Nev. & $1978-92$ \\
\hline 34 & USGS & 10311100 & Kings Canyon Creek near Carson City, Nev. & $1978-92$ \\
\hline 35 & USGS & 10311200 & Ash Canyon Creek near Carson City, Nev. & $1978-92$ \\
\hline 36 & USGS & 10311260 & $\begin{array}{l}\text { Vicee Canyon Creek near Sagebrush Ranch near } \\
\text { Carson City, Nev. }\end{array}$ & 1983-85, 1989-ח2 \\
\hline 37 & CCWTP & 391036119422401 & $\begin{array}{l}\text { Carson City Wastewater Treatment Plant effluent } \\
\text { discharge, Nev. }\end{array}$ & $1978-86$ \\
\hline 38 & USGS & 10311300 & Eagle Valley Creek at Carson City, Nev. & $1985-92$ \\
\hline 39 & USGS & 10311400 & Carson River at Deer Run Road near Carson City, Nev. & 1979-85, 1990-ח \\
\hline 40 & FWM & C62 & Rose Ditch near Dayton, Nev. & $1978-92$ \\
\hline 41 & FWM & $\mathrm{C} 63$ & Dayton (Randall) Ditch near Dayton, Nev. & $1978-92$ \\
\hline 42 & FWM & C64 & Fish Ditch near Dayton, Nev. & $1978-92$ \\
\hline 43 & FWM & $\mathrm{C} 65$ & Baroni Ditch near Dayton, Nev. & $1978-92$ \\
\hline 44 & FWM & $\mathrm{C} 66$ & Rock Point and Cardelli Ditches near Dayton, Nev. & $1978-92$ \\
\hline 45 & FWM & C67 & Quillici Ditch near Dayton, Nev. & $1978-92$ \\
\hline 46 & FWM & C68 & Gee Ditch near Dayton, Nev. & $1978-92$ \\
\hline 47 & FWM & C69 & Chaves (Koch) Ditch near Dayton, Nev. & $1978-92$ \\
\hline 48 & FWM & $\mathrm{C} 70$ & Houghman and Howard Ditch near Fort Churchill, Nev. & $1978-92$ \\
\hline \multirow[t]{2}{*}{49} & FWM & C71 & Buckland Ditch near Fort Churchill, Nev. & $1978-92$ \\
\hline & USGS & 10311900 & & \\
\hline 50 & USGS & 10312000 & Carson River near Fort Churchill, Nev. & $1978-92$ \\
\hline 51 & USGS & 10312100 & Lahontan Reservoir near Fallon, Nev. ${ }^{2}$ & 1978-92 \\
\hline 52 & USGS & 10312150 & Carson River below Lahontan Dam near Fallon, Nev. & $1978-92$ \\
\hline
\end{tabular}
year ends.

${ }^{1} \mathrm{~A}$ water year is defined as the 12-month period beginning October 1 and ending September 30 , and designated by the calendar year in which the water

${ }^{2}$ Lake levels recorded at Lahontan Reservoir near Fallon, Nev. 
The USGS has several gaging stations along the mainstem Carson River and tributaries that are typically operated all year (U.S. Geological Survey, 1979-95); however, data were not collected at all gaging stations for the entire period (table 1). The average accuracy of the streamflow record of each USGS gaging station can be used to assess the quality of the data. Accuracy of USGS gaging stations in the study area areas was adversely affected at times because of equipment malfunction, backwater conditions from downstream irrigation structures, changes in channel hydraulics, and low streamflow conditions. The USGS defines accuracy of daily streamflow data as excellent, good, fair, or poor (U.S. Geological Survey, 1992, p. 20):

Excellent means that about 95 percent of the daily discharges are within 5 percent of their true values; good within 10 percent; and fair within 15 percent. Records that do not meet the criteria mentioned are rated poor. Different accuracies may be attributed to different parts of a given record.

The U.S. District Court Water Master, also called the Federal Water Master (FWM), operates gaging stations on many irrigation ditches along the Carson River. Flow data typically are collected from these stations only during the irrigation season. (The irrigation season is usually the seven month period beginning April 1 and ending October 31 of any given year.) The FWM gaging-station network for Carson River diversion can be divided into two groups: stations upstream from Carson City and stations downstream from Carson City. Diversion data were collected at most stations upstream from Carson City beginning in the spring of 1982 using continuous stage recorders. Data were collected from downstream ditch gages beginning 1978; these measurements, however, were discontinuous periodic readings of staff gages (two or three times weekly). The staff-gage readings can be used to determine average flow on that day. Diversion data from staff gages are not as accurate as data from continuous-recording gages. Accuracy of FWM records, as of USGS measurements, is affected by number of discharge measurements, equipment malfunctions, variable backwater conditions from downstream irrigation structures, undocumented irrigation-ditch spills returning to the mainstem river downstream from the diversion gage, and the frequency of visits to sites where intermittent data are collected. The accuracy of FWM gaging station records has not been quantified and such an evaluation is beyond the scope of this report.

Ungaged releases from Mud Lake are not accounted for by this study because flow data are not available. Carson City can store some of its municipal water supply in Mud Lake along the West Fork when typically released to the West Fork for delivery to Carson City in late summer and fall.

\section{Estimated Flow}

Although a great deal of streamflow and diversion data were compiled for this study, recceds were not always complete enough to generate time series to adequately describe the river's flow for all times and conditions. Where continuous streamf' data to quantify inflow to and outflow from the Carson River were unavailable, hydrologic techniques were used to estimate flow time series. For some periods of record, gaging stations did not always provide. continuous data required for time series or had records with significant errors because of problems and conditions mentioned previously. In addition, gaging stations are not located at all sites necessary to measure every inflow to or outflow from the Carson River. Observed flow data and estimated flow data were compiled in a comprehensive data base to support the flowrouting model. The estimated data may not be as accurate as gaging-station records, but reduce the potential error in the model simulations that would occur by omitting these inflows and outflows. Techniques used to estimate missing or incomplete time-series data for model input are described in the following paragraphs.

\section{Discontinuous Data}

Several FWM Carson River diversion gages downstream from Carson City had only discontinuous staff-gage readings taken several times per week during irrigation seasons. The gaps in flow data between readings were estimated by interpolation to create a continuous time series of daily data d iring irrigation seasons. Although this method may nct. indicate actual flow for days when the staff gages were not read, it was considered to produce an acceptable estimate. Accuracy of daily flow records from staff gages is lower than accuracy of data from contiriousrecording gaging stations because of the intermittent readings and because of the need to interpolate daily flow between readings. 


\section{Estimates for Ungaged Flow}

Hydrologic techniques were used to estimate flow for several components of the hydrologic system where no daily streamflow data were available. The following section describes methods to estimate (1) ungaged irrigation diversions and return flow, (2) ungaged tributary inflow, (3) treated-effluent discharges, and (4) ungaged ground-water inflow.

\section{Irrigation Diversions}

Ungaged ditch diversions had to be estimated for modeling some reaches. Although the FWM collects data at major irrigation ditches along the Carson River, the gaging-station network does not include every ditch. Decreed irrigated acreage at gaged ditches was determined from the Alpine Decree (U.S. District Court, 1980). Simple ratios of flow per decreed acre were determined for gaged diversion flow. Then decreed acres from nearby ungaged ditches were multiplied by the ratio to estimate ungaged diversions. Under the appropriative water-right concept in use in the Carson River Basin, this simple acreage ratio is not always representative, but this calculation provides a reasonable estimate of the magnitude of diverted flow. Errors for individual ditches probably increase as mainstem streamflow decreases, and as senior water rights begin to supersede junior water rights. Also, the complexity of estimating flows for individual irrigation ditches was reduced by combining several estimated irrigation diversions into one data set for each river reach.

Diversion data were unavailable for the entire 1982-83 irrigation seasons for several FWM irrigation ditches. A hydrographic comparison of diversion data from nearby gaged ditches was used to determine which years were similar to $1982-83$, and the similar year from the nearby gaged ditch was used to estimate data for 1982-83.

\section{Irrigatlon Return Flow}

Irrigation return flow can be defined as excess surface and ground water that returns to the mainstem after irrigation and, to a lesser degree, ground water entering the river. Like diversion flow from many of the minor ditches, return flow from irrigation ditches and canals is rarely gaged. However, on the basis of low-flow investigations, irrigation-efficiency studies, soil type, depth to water, and location within the Carson
River Basin, a time series was developed for each irrigation ditch that estimated return flow as a constant percent of the diversion. Although imprecise, these estimates (described in a later section) of return flow' provide a probable magnitude of net flow diverted. Low-flow investigations are serial, nearly concurrent streamflow measurements along the length of the river to determine areas or points of gain or loss along a river. Several USGS low-flow investigations (U.S. Geological Survey, 1976, 1992, and 1993) have been used to estimate irrigation-ditch return flow in the Carson River Basin.

The U.S. District Court Water Master (Julian Larrouy and Ed Mees, oral commun., 1993) has pro. vided general information on typical irrigation practices and ditch return flow in specific areas of the basin. Irrigation efficiency can be an indicator of soil type and depth to water, both of which greatly affect seepage from unlined canals and laterals, as well as return flc $\times$ of water applied to the fields. Guitjens and Mahannah $(1975 ; 1977)$ documented how irrigation efficiency in 1974-75 varied with location in the Carson Valley and the time of year. Studies on several ranches in Carson Valley from 1963-68, conducted by the Carson Water Subconservancy District, computed an average irrigation efficiency for those years of 32 percent (ClyceCriddle-Woodward, Inc., 1971, p. G-4). Maps of soil types and depth to water are available for most of the upper Carson River Basin (Maurer, 1986; ClydeCriddle-Woodward, Inc., 1971) and were used to estimate return flow in areas where irrigation-efficiency has not been studied. The Pyramid Lake Task Force (1971) has determined soil types and general seepace rates of several specific ditches along the Carson Rivar.

Even for ditches that have a FWM gage, not all the return flow is measured; spills from the ditch that return to the river downstream from the gaging station also need to be estimated. Based on FWM notes, calculations were made to estimate these ungaged spills. FWM typically collects data from their network of ditch gages only during the irrigation season. Some water is diverted, however, during the non-irrigation periods to provide stockwater. These stockwater diversions are typically much less than irrigation diversions, and as noted on several field observations, the retum flow is nearly equal to the stockwater diversion; the"efore, stockwater diversion in ditches in the non-irrication season is assumed no net stockwater diversion. 


\section{Tributary Inflow}

Streamflow from ungaged tributaries into the reaches modeled in this study also needed to be estimated. Most ungaged, perennial tributaries are in the mountainous reaches of the East Fork and West Fork between the towns of Markleeville and Woodfords and Carson Valley. Streamflow for Indian Creek, a tributary to the East Fork Carson River, was not estimated because the gaging stations were upstream from many of the irrigation diversions. Streamflow from these intervening tributary drainage areas was estimated for the East Fork Carson River upstream from Gardnerville for water years 1978-82 using the gaging station Bryant Creek near Gardnerville, Nev. (site 2; pl. 1), as an index station. The ratio of the Bryant Creek drainage area to the areas of the ungaged intervening tributary drainage was determined and the time-series data for observed Bryant Creek streamflow was multiplied by that ratio. No tributary inflows were estimated subsequent to 1982 because the period of record for the index station ends in 1982. A regression analysis compared several observed tributary index stations to mainstem streamflows and the analysis indicated poor statistical relations. The regression analysis provided poor results because the period of record for most of the index stations was from 1987 to 1992 . This period is characterized by mostly average to drought runoff conditions. No index gaging station was suitable to estimate tributary inflow for the West Fork. Downstream from Carson Valley on the Carson River, most of the ungaged tributaries are ephemeral and as a result do not normally supply a large volume of water to the Carson River. These tributaries reach the Carson River only during periods of extreme high runoff (Rhea $P$. Williams, U.S. Geological Survey, oral commun., 1993). Ungaged tributary inflow from reaches on the mainstem Carson River downstream from Carson Valley were not estimated because flow data were not available.

\section{Treated-Effluent Discharges}

Several wastewater-treatment facilities provide secondary or tertiary treated effluent for irrigation, and they historically discharged into the Carson River at several sites in Carson Valley and Carson City (Nevada Division of Environmental Protection, 1982, p. II-25-34). After 1987, direct discharge of treated effluent to the Carson River ceased. These discharges were generally estimated by wastewater-treatmentplant personnel on a monthly basis. Assuming th at effluent discharges did not vary significantly in a month, the monthly discharges were converted to estimated daily discharges by dividing by the number of days per month. During some periods, effluert was used for irrigation before reaching the river. The estimates of effluent discharges for such periods were decreased based on estimates of irrigation consumption provided by plant personnel. Discharge of treated effluent to the Carson River was estimated only from 1978 to 1987.

\section{Ground-Water Inflow}

For areas where ground water contributes to streamflow, time series for ground-water inflow were estimated. During irrigation season, inflow to the Carson River from ground water is difficult to define by water-budget computations based on data from mainstem and ditch diversion gages, because the ditch diversions are usually estimated and the gaging stations are located too far apart. Several studies identify general areas of ground-water inflow (Maurer, 1986; Worts and Malmberg, 1966), and several USGS low-flow investigations (U.S. Geological Survey, 1976, 1992, and 1993) indicate the reaches where ground-water inflows are significant and provide estimates of the magnitude of the inflows. During the spring, the Carson River often floods the bottom lands of Carson Valley, contributing to both ground-water storag and surface ponded areas in the valley. Maurer (1986, p. 63) and Clyde-Criddle-Woodward, Inc. (1971, p. 21) demonstrated that rates of ground-water inflow vary throughout any given year. Because the variability in the annual distribution of ground-water inflow c culd not be described quantitatively in this flow-routing model, this study used constant estimates of inflow for those reaches where ground-water contributions were judged to be significant from 1978 to 1992 (table 2; reach characteristics will be described later).

\section{Hydraulic Data}

In the model, hydraulic characteristics of the reaches-including channel shape, roughness, slope, and length-determine how streamflow is stored in a reach. Hydraulic properties of the river are assumed to not change significantly with time. Data for 32 cross sections were compiled from previous studies; 
representative cross sections from these previous studies were verified by field surveys and were found to be within the accuracy $(0.5 \mathrm{ft})$ needed for this study. In Douglas County, parts of the cross-sectional survey data for the East Fork and Brockliss Slough were provided by the U.S. Department of the Army, Corps of Engineers (Federal Emergency Management Agency, 1986, 1992a). In Carson City, cross-sectional surveys along a part of the Carson River were done by the USGS (Federal Emergency Management Agency, 1989). In Lyon County, cross-sectional surveys along the Carson River were obtained from Nimbus
Engineers (Federal Emergency Management Agency, 1992b). Spot altitudes were determined from aerial photography in 1977 and from topographic maps with 5-ft contour intervals (Carson Valley Conservation District, 1988), and flood-plain altitudes were provided by U.S. Department of the Army (1986). A comparisnn of cross-sectional data from field surveys and from digital elevation models (DEM) within geographic information system data bases demonstrated that DEM data (U.S. Geological Survey, 1987b) were not with in the 0.5 -ft accuracy needed for this study; therefore, no supplemental DEM cross-sectional data were used.

Table 2. Selected reach characteristics of East Fork Carson River, West Fork Carson River, Brockliss Slough, and mainstem Carson River used to describe hydraulic properties and ground-water outflow in flow-routing models

\begin{tabular}{|c|c|c|c|c|c|c|c|}
\hline $\begin{array}{l}\text { Reach } \\
\text { no. } \\
\text { (pl. 1) }\end{array}$ & $\begin{array}{l}\text { Reach } \\
\text { length } \\
\text { (miles) }\end{array}$ & $\begin{array}{l}\text { Reach } \\
\text { slope } \\
\text { (foot per } \\
\text { foot) }\end{array}$ & $\begin{array}{c}\text { Estimated } \\
\text { ground-water } \\
\text { outflow (cubic } \\
\text { feet per second) }\end{array}$ & $\begin{array}{c}\text { Reach } \\
\text { no. } \\
\text { (pl. 1) }\end{array}$ & $\begin{array}{l}\text { Reach } \\
\text { length } \\
\text { (miles) }\end{array}$ & $\begin{array}{l}\text { Reach } \\
\text { slope } \\
\text { (foot per } \\
\text { foot) }\end{array}$ & $\begin{array}{c}\text { Estimated } \\
\text { ground-water } \\
\text { outflow (cubic } \\
\text { feet per second) }\end{array}$ \\
\hline \multicolumn{4}{|c|}{ East Fork Carson River } & \multicolumn{4}{|c|}{ Brockliss Slough } \\
\hline 1 & 3.25 & 0.0053 & -- & 23 & 1.22 & 0.0025 & -- \\
\hline 2 & 2.85 & .0062 & -- & 24 & 2.04 & .0026 & -- \\
\hline 3 & 3.85 & .0048 & -- & 25 & 1.90 & .0020 & -- \\
\hline 4 & 2.91 & .0048 & -- & 26 & 2.23 & .0020 & -- \\
\hline \multirow[t]{2}{*}{5} & 1.79 & .0043 & -- & 27 & 1.96 & .0016 & - \\
\hline & & & & 28 & 2.92 & .0018 & -- \\
\hline 6 & 4.03 & .0037 & -- & & & & \\
\hline 7 & 2.39 & .0055 & -- & \multicolumn{4}{|c|}{ Carson River } \\
\hline 8 & 1.29 & .0064 & -- & & & & \\
\hline 9 & 2.98 & .0031 & -- & 29 & 2.22 & .0013 & -- \\
\hline 10 & 2.63 & .0030 & -- & 30 & 2.91 & .0005 & -- \\
\hline \multirow[t]{3}{*}{11} & 2.32 & .0016 & -- & 31 & 3.55 & .0008 & -- \\
\hline & & & & 32 & 3.45 & .0007 & -- \\
\hline & \multicolumn{3}{|c|}{ West Fork Carson River } & 33 & 3.27 & .0015 & -1.7 \\
\hline 13 & 1.39 & .0290 & -- & 34 & 4.03 & .0015 & -2.5 \\
\hline 14 & 1.82 & .0240 & -- & 35 & 3.86 & .0044 & -1.6 \\
\hline 15 & 2.36 & .0117 & -- & 36 & 2.93 & .0061 & -.7 \\
\hline 16 & 2.47 & .0081 & -- & 37 & 3.87 & .0032 & -. \\
\hline 17 & .89 & .0025 & -- & 38 & 3.30 & .0010 & -- \\
\hline 18 & 3.69 & .0033 & -- & 39 & 2.45 & .0085 & -- \\
\hline 19 & 1.92 & .0023 & -- & 40 & 2.02 & .0012 & - \\
\hline 20 & 2.54 & .0022 & -- & 41 & 3.36 & .0012 & -3.8 \\
\hline \multirow[t]{3}{*}{21} & 2.12 & .0007 & -- & 42 & 3.65 & .0007 & -- \\
\hline & \multirow{2}{*}{\multicolumn{3}{|c|}{ Carson River }} & 43 & 4.43 & .0008 & -- \\
\hline & & & & & & & \\
\hline \multirow{5}{*}{22} & & & & 44 & 2.81 & .0007 & -- \\
\hline & 1.29 & .0010 & -- & 45 & 3.12 & .0003 & -- \\
\hline & & & & 46 & 3.73 & .0002 & -- \\
\hline & & & & 47 & 2.08 & .0006 & -- \\
\hline & & & & 48 & 1.72 & .0004 & -- \\
\hline
\end{tabular}


Ninety-six cross sections were surveyed by the USGS to determine hydraulic characteristics for those reaches where no data were available or data were inaccurate. Field surveys included measuring the channel cross section up to the approximate altitude of highest flood, selecting roughness coefficients, and describing auxiliary channels. Cross sections were generally surveyed, within $0.1 \mathrm{ft}$, at representative locations about every mile along the mainstem channels, but data collection was somewhat limited by access to lands in the Carson Valley.

\section{Division of River into Reaches}

As described in a previous section, the unsteadyflow-routing block of HSPF simulates river flow by the hydraulic definition of river reaches as if they were a series of interdependent reservoirs. These reaches are generally 2 to $3 \mathrm{mi}$ long. The reach boundaries selected for the flow-routing model were based on locations of breaks in bottom slope of the main channel, tributary inflow, diversion points, diversion returns, locations of gaging stations, and state boundaries-primarily places where the hydraulic characteristics change the magnitude of flow changes, or at political boundaries. The East Fork Carson River was divided into 11 reaches along the $31.7 \mathrm{mi}$ studied and the West Fork was divided into 9 reaches along the $19.2 \mathrm{mi}$ studied (table 3; full and submodels will be described later). Brockliss Slough was divided into 6 reaches along its 12.3-mi length, and the Carson River was divided into 20 reaches along the $62.8 \mathrm{mi}$ studied. For modeling different water-management practices on the Carson River, reach boundaries (table 3 ) also coincide with six of the eight segment boundaries delineated in the Alpine Decree (U.S. District Court, 1980). Carson River reach inflows and outflows are shown in table 4 (return flow will be discussed later).

\section{Hydraulic Characteristics of Reaches}

Implementation of the HSPF flow-routing model requires detailed description of the hydraulic characteristics of the connected reaches of the stream being simulated. The comprehensive set of hydraulic data must depict the cross-sectional features of each reach. Cross-sectional surveys were completed at an average of two sites within each reach to obtain the hydraulic data. The sites for each reach were considered to be the most representative of the relation between stage and volume for that reach and between stage and discharge at the downstream end of the reach (approximated from USGS gaging-stations streamflow records). Other data required - such as channel length and average channel slope (table 2)-were determined from a geographic information system using 1:24,000-scale maps (methods described by Cartier and others, 1994). The Channel Geometry Analysis Program (CGAP) (Regan and Schaffranek, 1985) uses the Manning equation to compute cross-sectional hydraulic features of each reach and provides graphical representations of both stage-discharge relations and plots of cross sections. Plots provided a means if visually checking the data for errors in input. HSPF stored these cross-sectional data and the channel geometry from CGAP in tabular form in FTABI.E for direct input into the HSPF model.

\section{Flow Bifurcation}

The West Fork Carson River bifurcates near Dresslerville into the West Fork (reach 17; pl. 1) and Brockliss Slough (reach 23) in Carson Vallev. A control structure on the West Fork regulates flow down the West Fork below Brockliss Slough. Most of the water at that point flows down Brockliss Slough, whereas the West Fork is mostly used as a catchment for irrigation return flow from the western side of the East Fork. Modeling streamflow for 1978-92 using HSPF requires an estimate of how the flow divides; however, no streamflow data are collected at the split. Streamflow data are collected upstream of the bifurcation (West Fork Carson River at Dressler Lane near Fredericksburg, Calif.; site 25; pl. 1) and on the Brockliss Slough downstream from the split (Brockliss Slough at Ruhenstroth Dam near Gardnerville, Nev.; site 26; pl. 1). These data were used to estimate the division of streamflow for the 1978-92 model and the estimates were put into FTABLE for direct input into HSPF at reaches 17 and 23. In addition to water budgets using the two gaging stations, field observations, and information obtained from FWM (Julian Larrouy, oral commun., 1993) indicate that when the streamflow in the West Fork is less than about $80 \mathrm{ft}^{3} / \mathrm{s}$, all flow is diverted to Brockliss Slough. Thus for West Fork flows up to about $80 \mathrm{ft}^{3} / \mathrm{s}$, the model routes all fow to the Brockliss Slough and when streamflow exceeds about $80 \mathrm{ft}^{3} / \mathrm{s}$, flow from the West Fork is split between the Brockliss Slough and the West Forlas demonstrated by water-budget computations. 


\section{Designation of Full Model and Submodels}

One full model and two submodels were constructed to simulate Carson River streamflow (table 3) and test the adequacy of the model. Data from the gaging stations at East Fork Carson River near Markleeville, Calif. (site 1), and West Fork Carson River at Woodfords, Calif. (site 19; pl. 1), were used to define the upstream inflow in the full model. Although simulation results were compared to observed streamflow records at all mainstem gaging stations along the Carson River, simulation results evaluated at only five of the gaging stations are presented in this report. The accuracy of gaging-station records was evaluated quantitatively for each year.

The submodels represent shorter lengths of river. The gaging stations at East Fork Carson River near Gardnerville, Nev. (site 3; pl. 1), and West Fork Carson River at Woodfords, Calif., were used to define the upstream inflow in this model. (The Gardnerville gaging station was selected as the upstream boundary of the upper submodel to test the accuracy of the streamflow data from the Markleeville gaging station used in the full model.) The upper submodel simulates streamflow along 27 reaches (reaches 6-32) from the upstream boundary to the Carson River near Carson City, Nev. (site 32). Simulation results were evaluated by comparison with actual records at the two gaging stations East Fork Carson River near Minden, Nev. (site 16), and Carson River near Carson City, Nev. (site 32).

The lower Carson River submodel simulates streamflow along 17 reaches (reaches 33-48; table 3). The gaging station Carson River near Carson City, $\mathrm{Nev}$, was used to define the inflow to the lower submodel. Simulation results were evaluated by comparison with records at the two gaging stations Carson River near Deer Run Road (site 39) and Carson River near Fort Churchill, Nev. (site 50).

\section{SIMULATION OF STREAMFLOW USING DAILY FLOW-ROUTING MODEL}

Simulations of streamflow were made by constructing a preliminary daily flow-routing model using HSPF for the Carson River for water years 1978-92. Time-series data used by the model represented all available information on inflow and outflow from the river model. Model input files, sizes, and description of computer files are listed in the appendix.
For this model, if these time-series data represent all Carson River inflow and outflow, and if the model parameters adequately represent the hydraulic characteristics of the Carson River reaches, then streamflcw would be adequately simulated. The following sections describe (1) how the flow-routing model was tested: (2) comparisons of observed and simulated daily streamflows evaluated for daily period; and (3) probable reasons for general and individual differences between observed and simulated streamflows, limitations of the model, and suggestions for improving the model.

\section{Model Testing}

The models must be tested against observed streamflow data before they can be relied upon to estimate conditions along the mainstem Carson River. After model construction, the observed inflow and diversion data were applied to these physically based models, and the three flow-routing models were tested by examining the difference between observed and simulated streamflow.

The goal of model testing, in contrast to calibration and validation, was to determine if differences between simulated and observed streamflow resulted because inadequate data were characterizirg the hydraulic features of the Carson River. If the dif:arences were related to timing of streamflow or magnitude of peak flow, then the fixed model parameters used may not adequately characterize Carson River hydraulics. The goal of traditional model calibration is to adjust values of model parameters to minimize. differences between simulated and observed strear.flow. For the Carson River daily flow-routing models, however, model parameters were not calibrated in a traditional sense to improve streamflow simulations. The model parameters were fixed to the values assigned by a modified kinematic-wave or storagerouting algorithm that routes flow through each reach. The only variable that can vary in this algorithm is $K S$, a weighting factor that is not physically measurable but that affects the timing of flow, and this factor may vary from 0 to 1.0. A value of $K S=0.5$ was assigned for all model simulations. Previous modeling studies (Dinicola, 1990, p.27; Berris, 1995) have used this value because, theoretically, it gives the most accur?te simulation results (Bicknell and others, 1993, p. 123). 


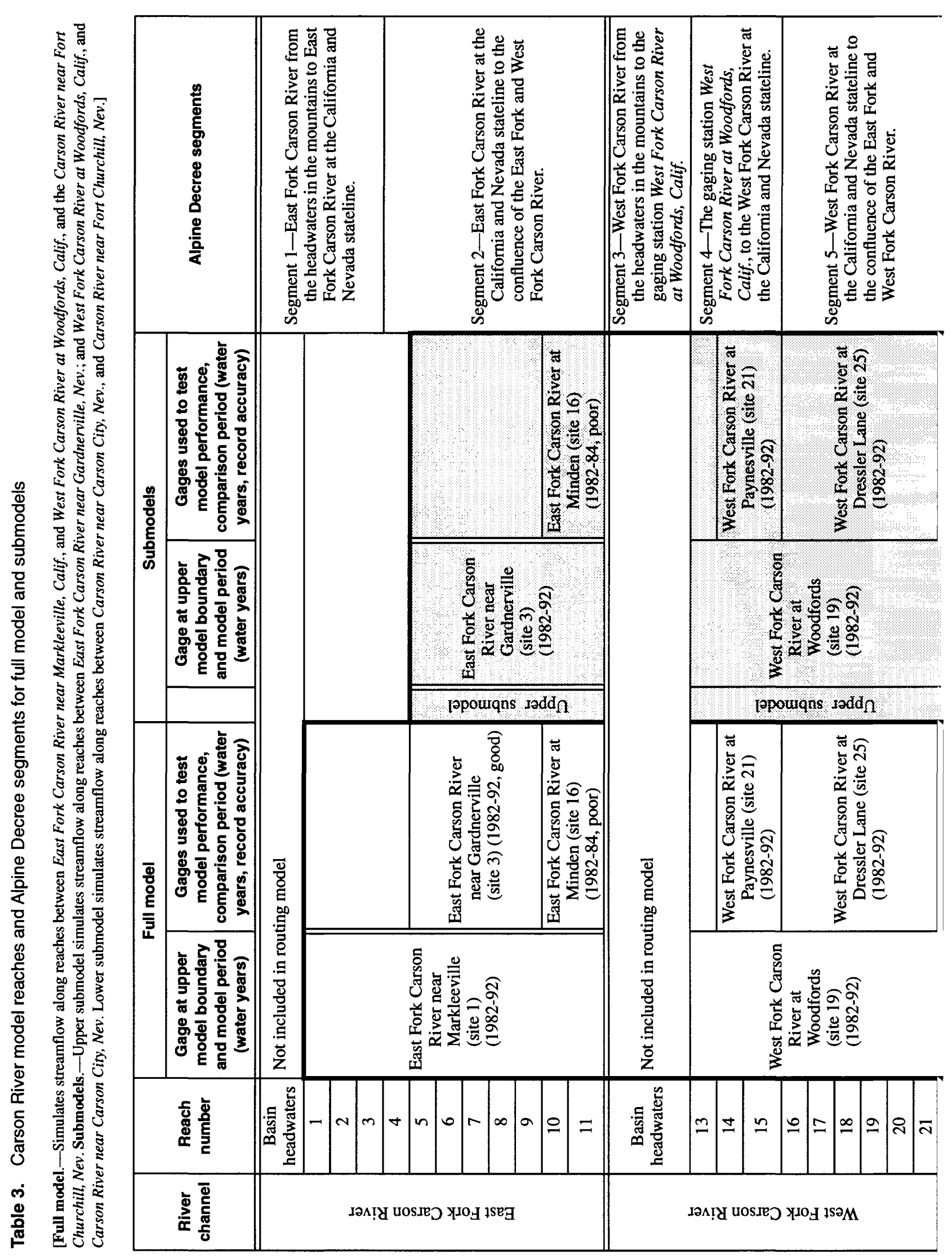




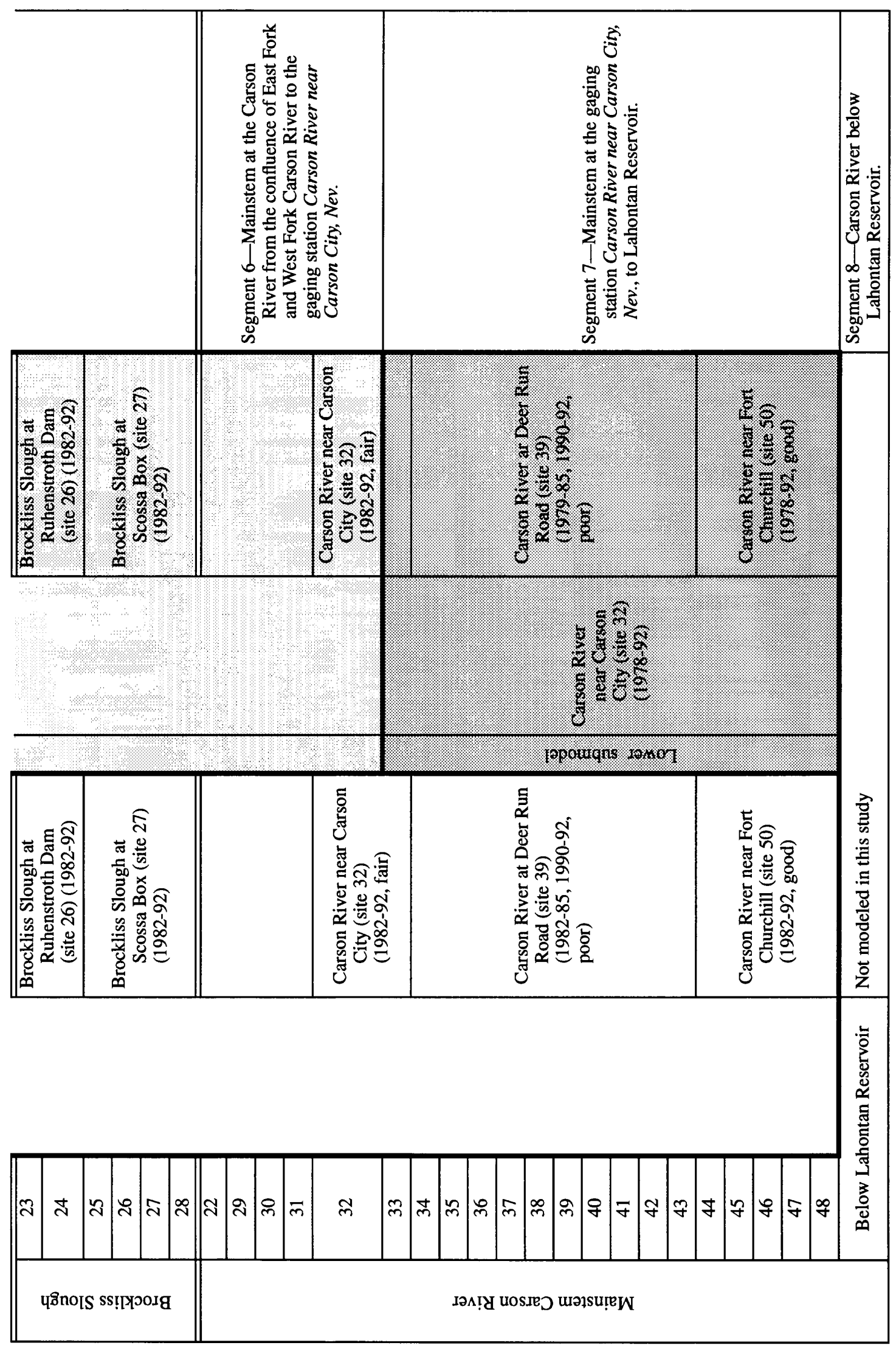




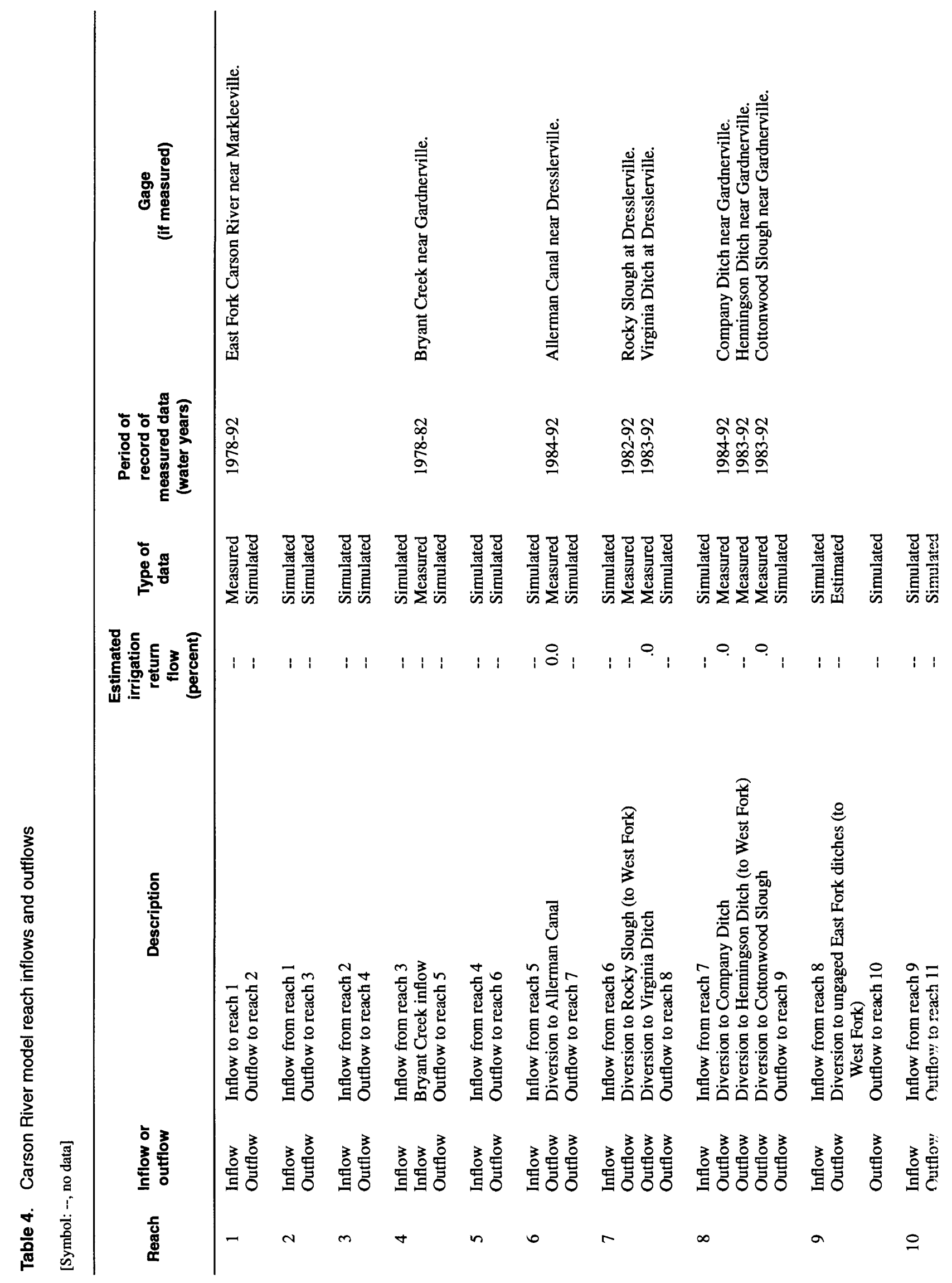



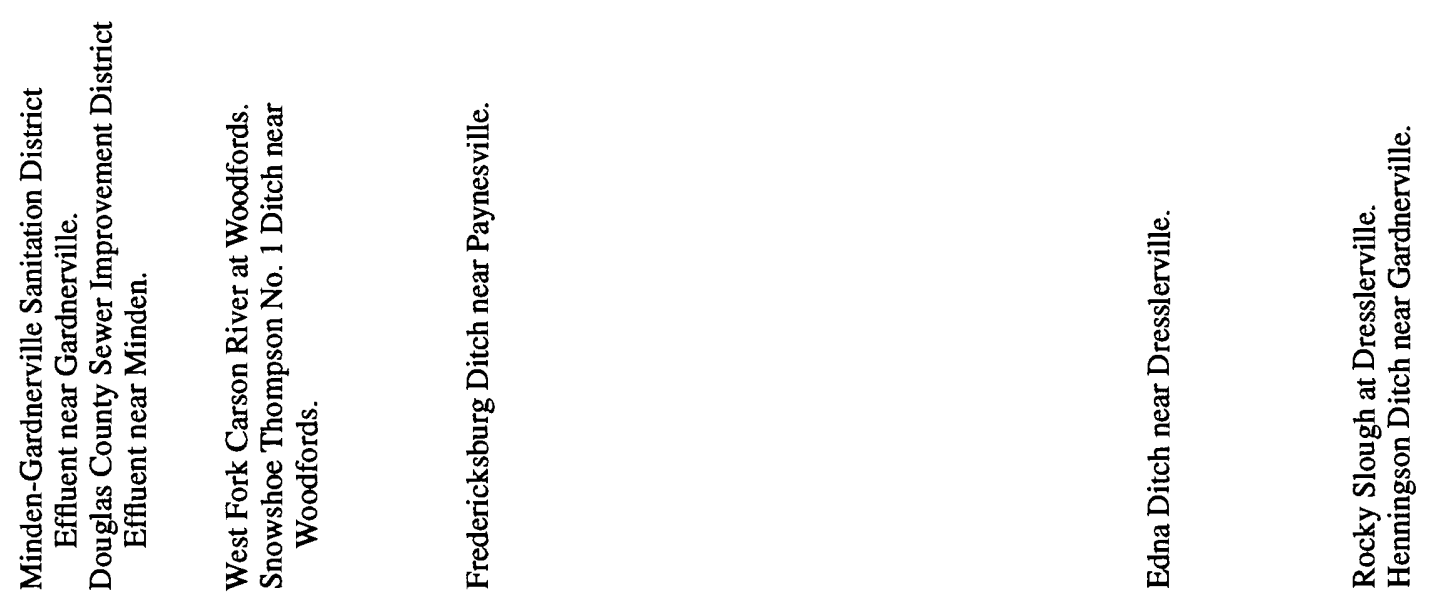

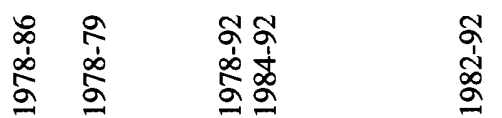

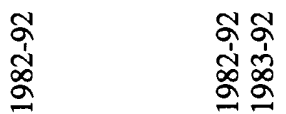

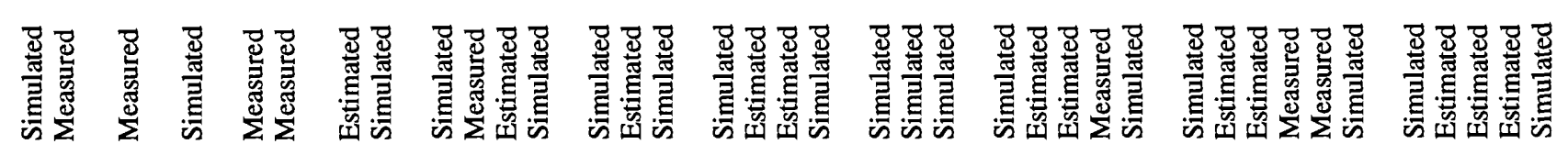

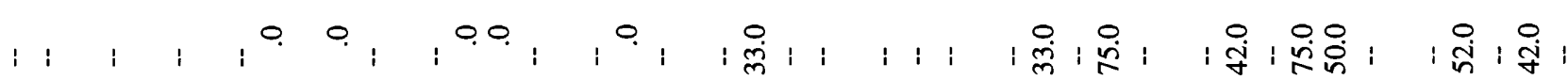

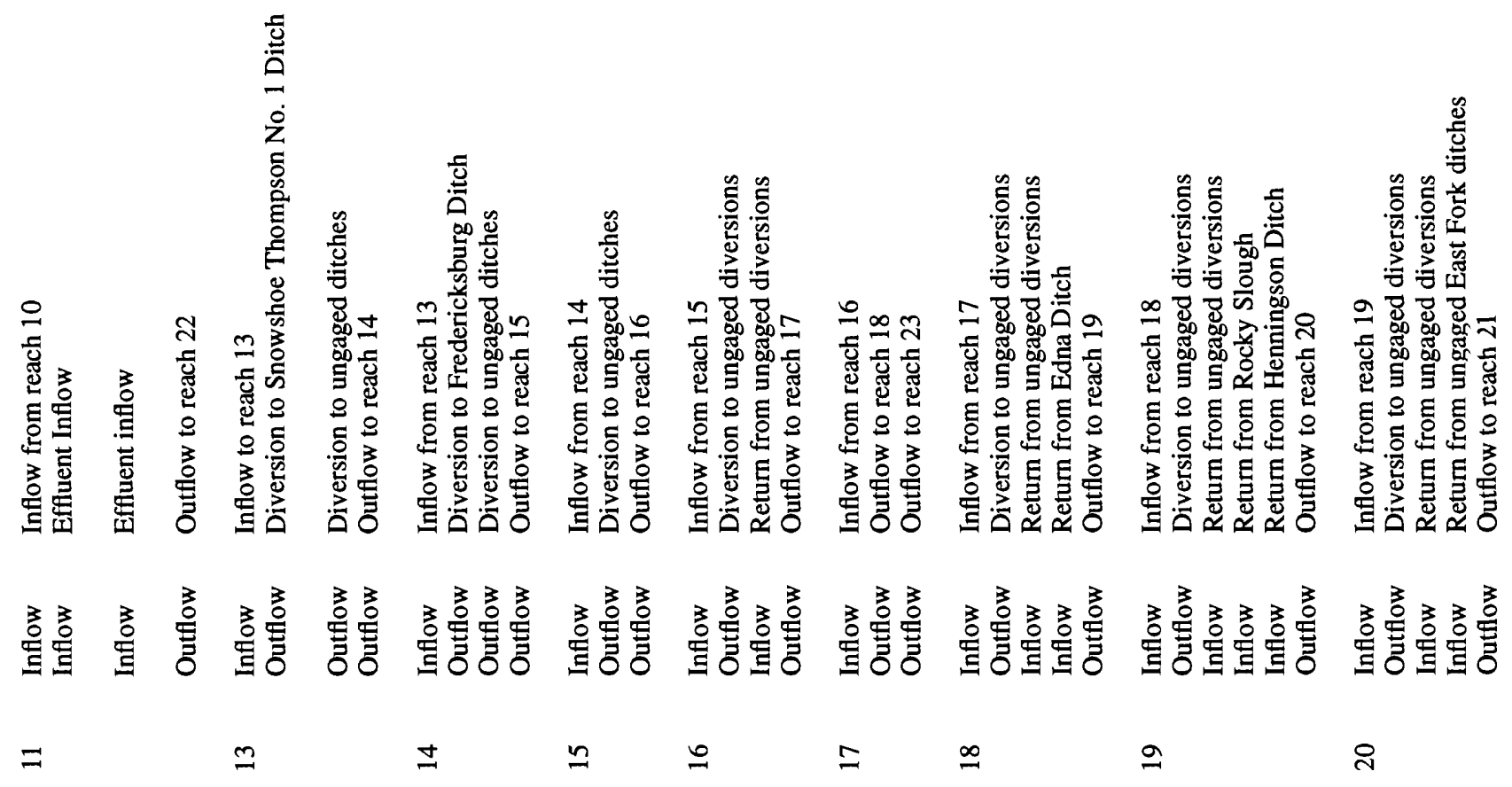




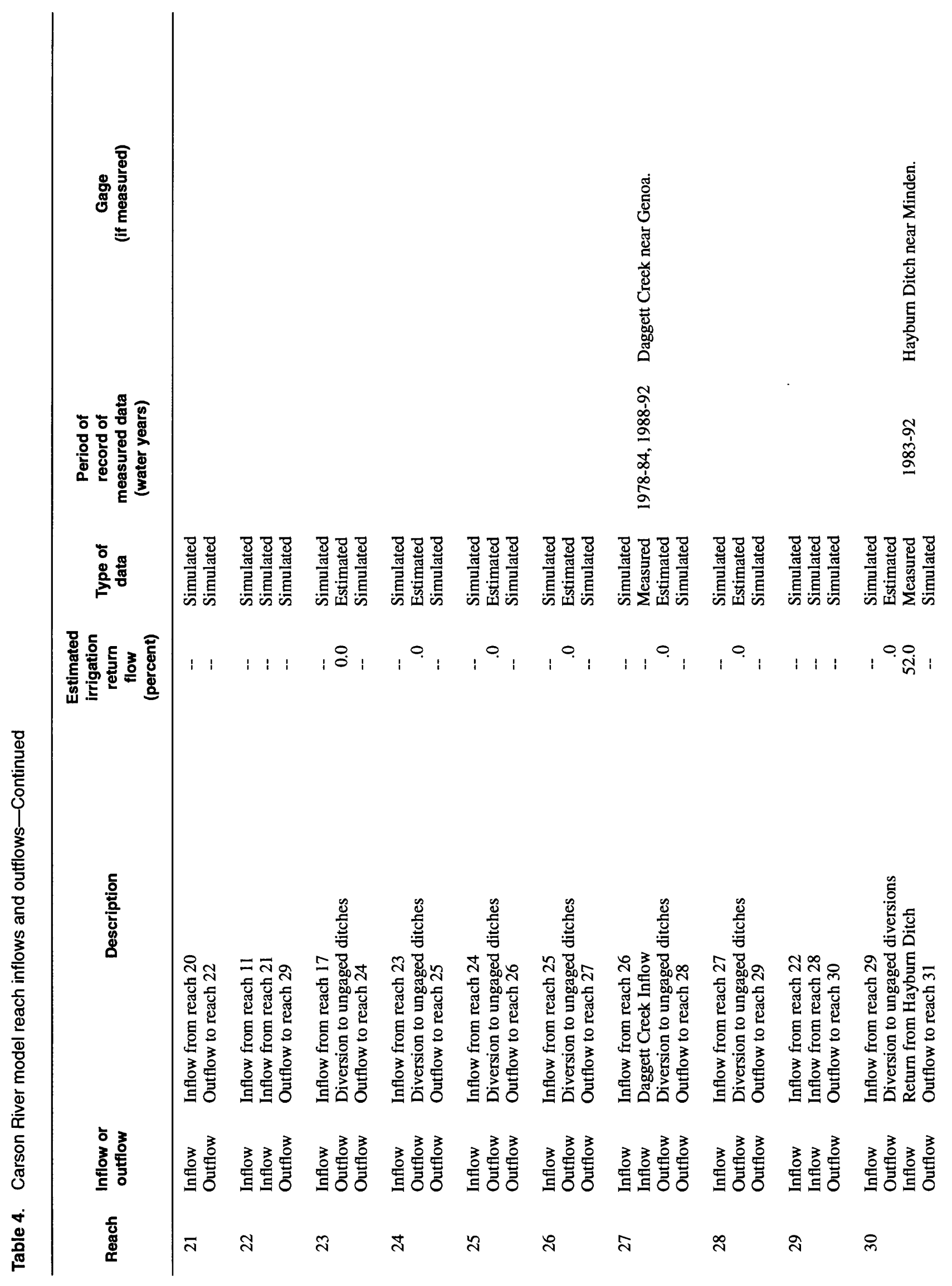



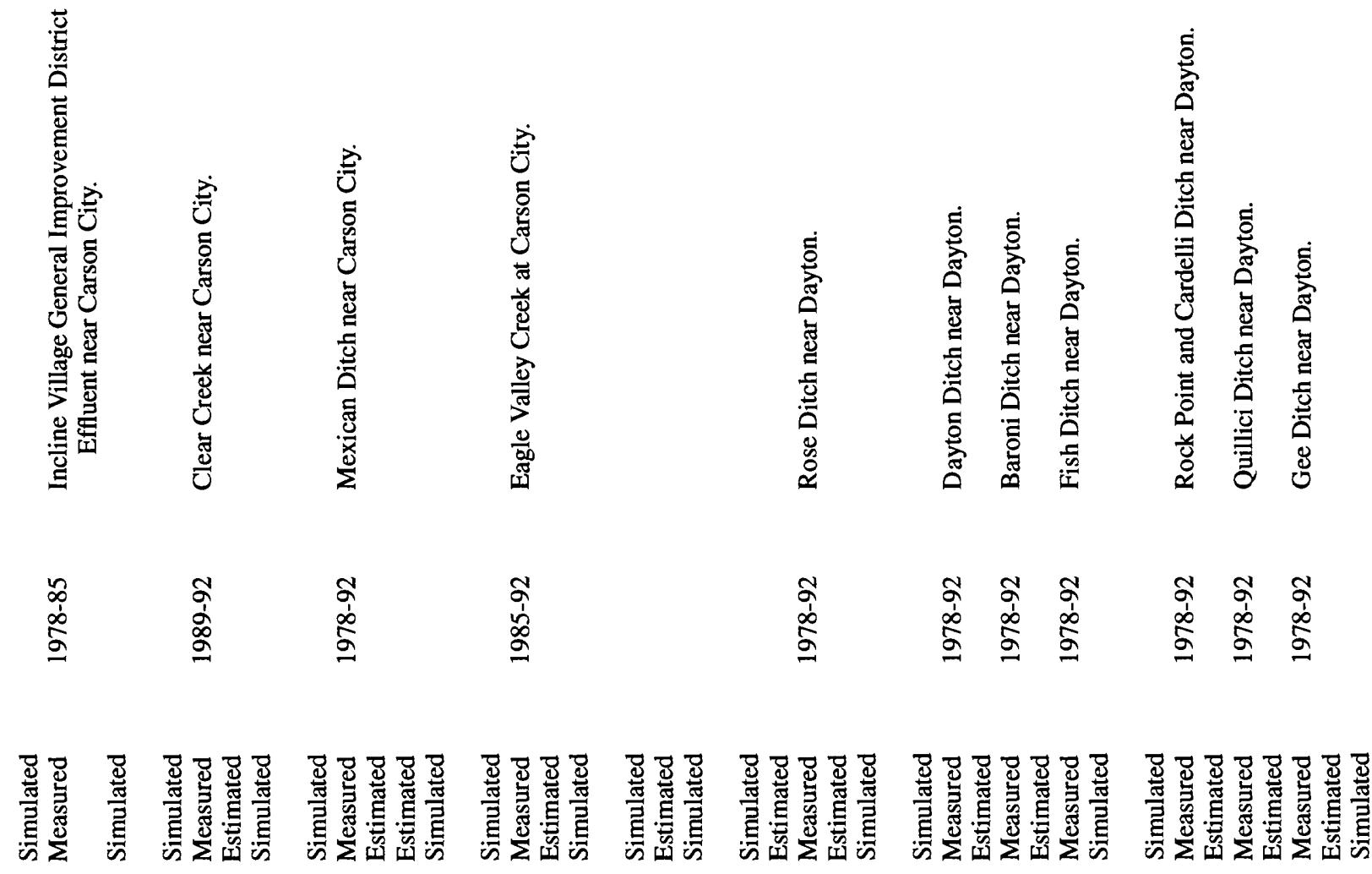

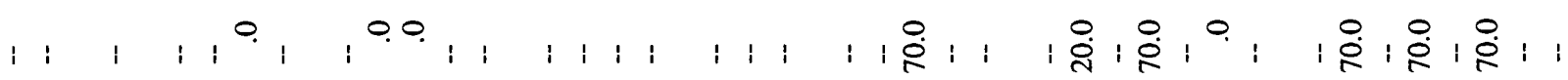

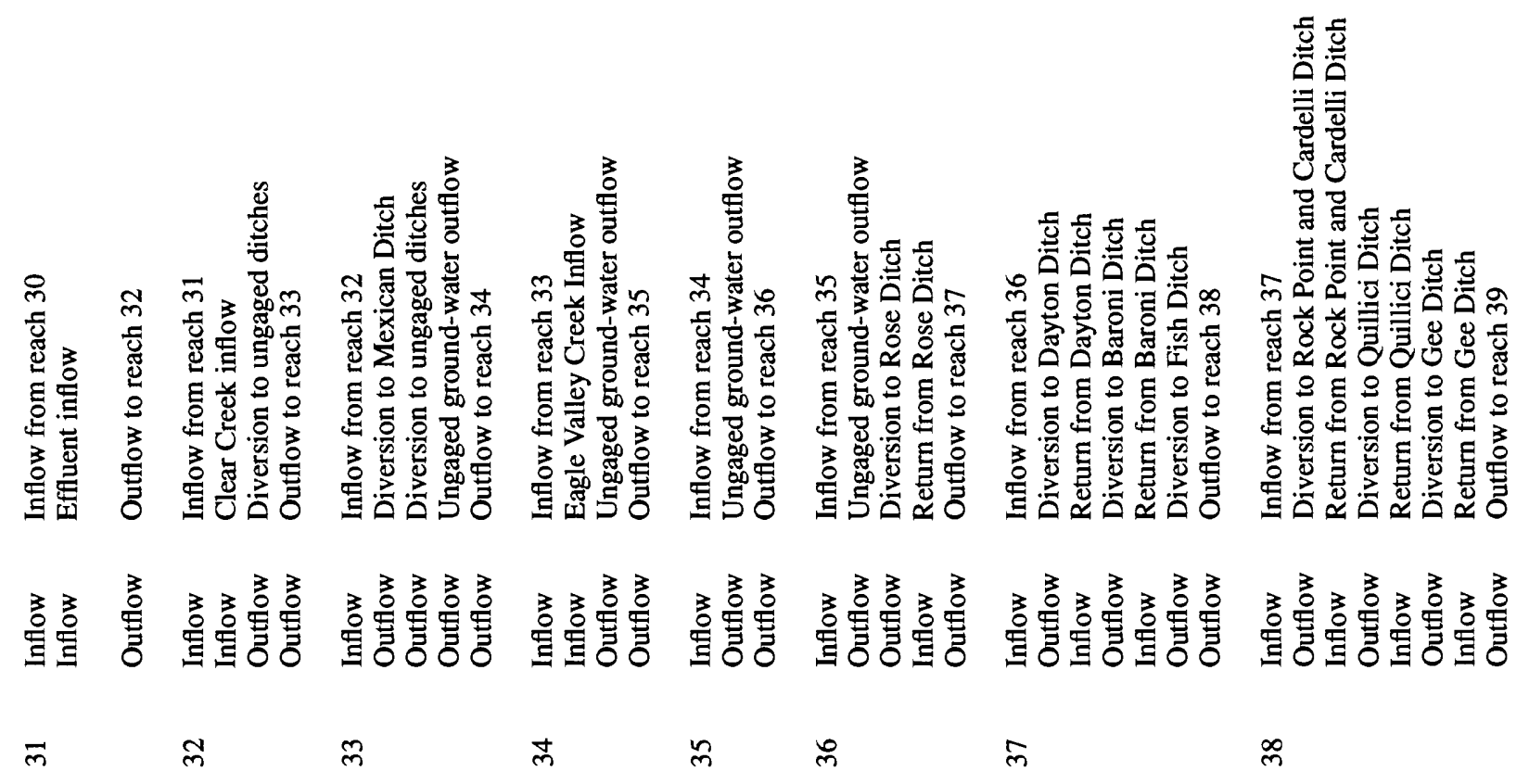




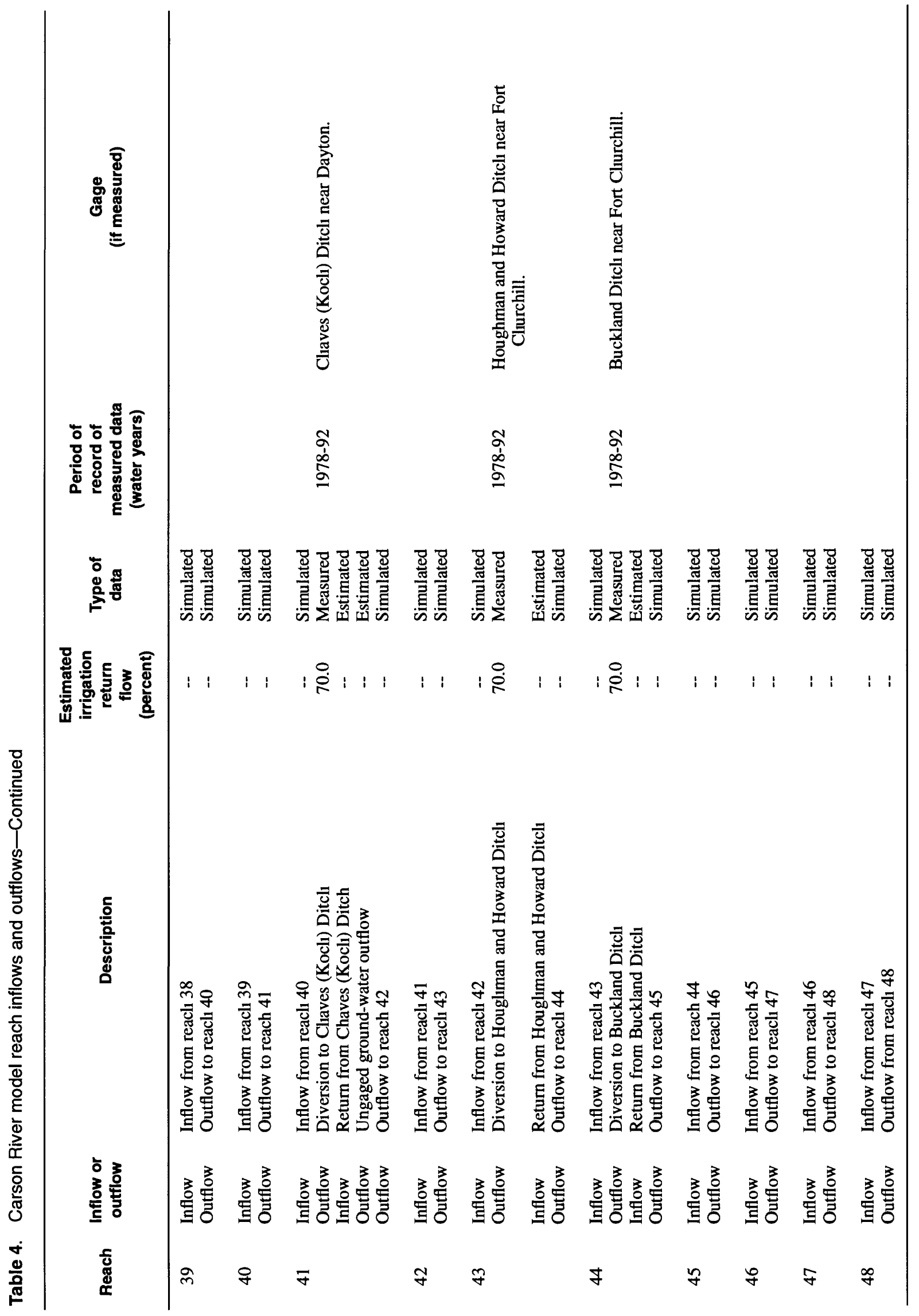


Model parameters representing hydraulic properties of cross sections within channel reaches were determined by field surveying and from maps. The FTABLES that incorporate these hydraulic properties can be adjusted to improve the timing of streamflow and magnitude of peak flow. However, these FTABLE adjustments affect simulated streamflows only for short periods of a few to several days. Hydrographs of
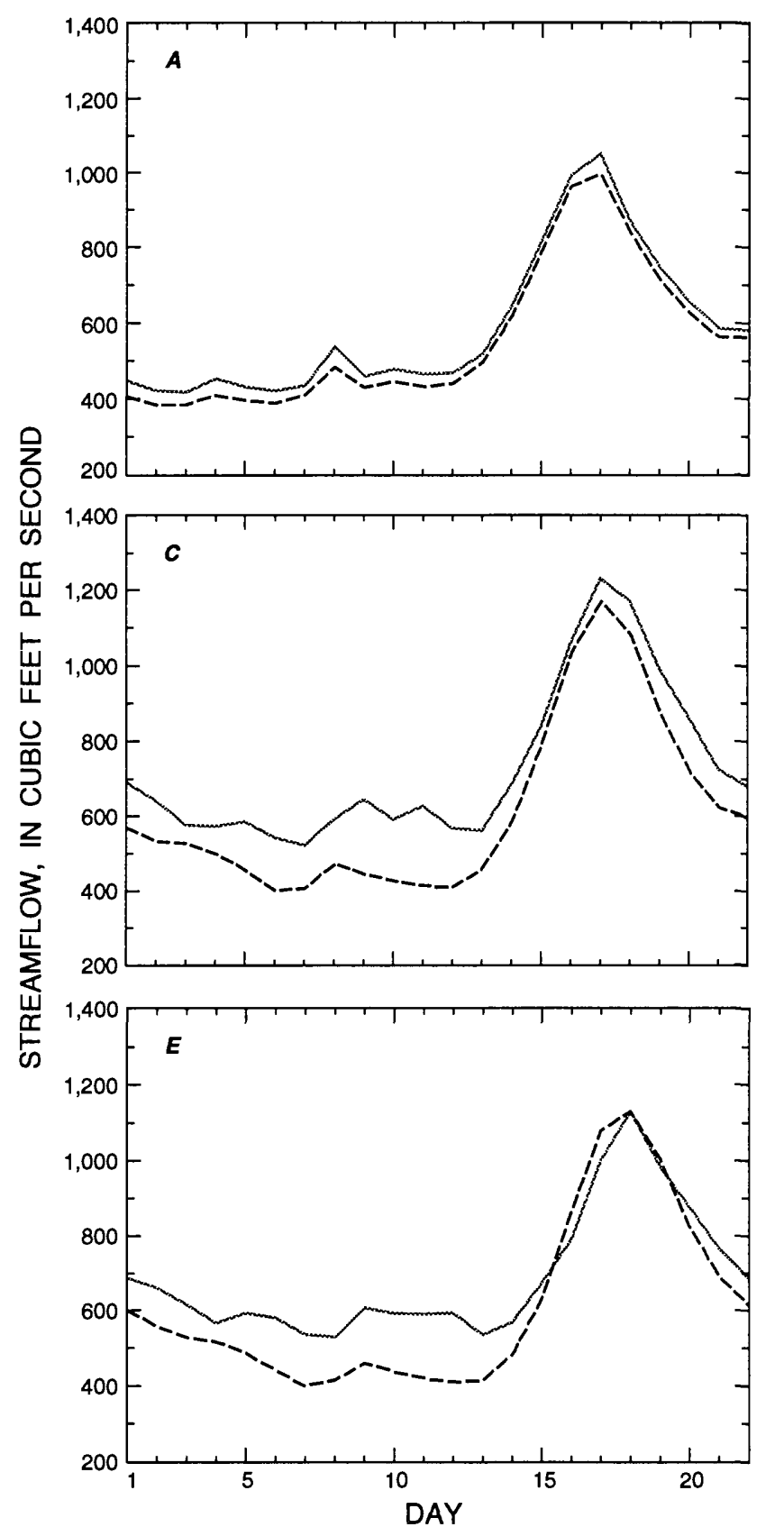

observed and simulated flow at five gaging stations were compared to determine if the fixed model parameters adequately characterize Carson River hydraulics. The hydrographs in figures $2 A-E$ show that timing of hydrographs for observed and simulated flow in the Carson River for April 1984 followed similar patterns at the five gaging stations - as the observed daily water levels rise or fall, the simulated daily flows rise or fall.
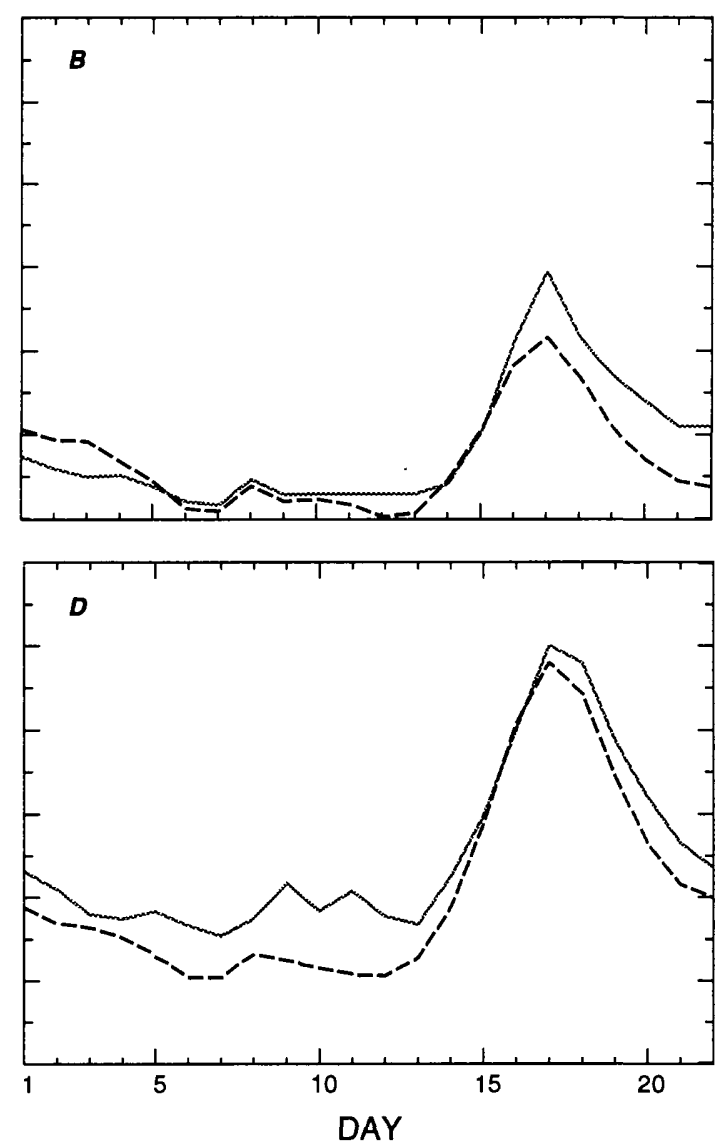

EXPLANATION

Observed streamflow SImulated streamflow

Flgure 2. Observed and simulated daily mean streamflow, April 1-22, 1984, full model. A. East Fork Carson River near Gardnerville, Nev. (site 3). B. East Fork Carson River at Minden, Nev. (site 16). C. Carson River near Carson City, Nev. (site 32). D. Carson River at Deer Run Road near Carson City, Nev. (site 39). E. Carson River near Fort Churchill, Nev. (site 50). (See sites on pl. 1) 
Periods with a range in streamflow help to demonstrate that hydraulic properties are adequately represented in FTABLES with the assumption that the physical characteristics of the streambed do not change during the study period 1978-92. Visual comparison of observed and simulated hydrographs showed that most of the differences are for periods ranging from several days to months, rather than for shorter periods. Differences between the magnitude of observed and simulated streamflow that extend for several days, as in figure 3, are probably due mostly to inadequate data for tributary inflows used as input to the model. In figure 3 , volume-related differences arise at high flows because tributary inflows are not modeled; the model simulates low flows more accurately because the ungaged tributaries contribute little water during low flow. Therefore, for this study, the FTABLES were not adjusted. In conclusion, the model testing indicates that the fixed model parameters do adequately characterize Carson River hydraulics and that the differences between observed and simulated streamflow mostly result from insufficient information to characterize irrigation diversions and returns, ground-water gains and losses, and tributary inflows. As more data are collected to characterize all parts of the water budget, the differences will become less, as described in subsequent sections. Because the model parameters were not truly calibrated, the models were not validated with streamflow observed in a period other than the selected simulation period.

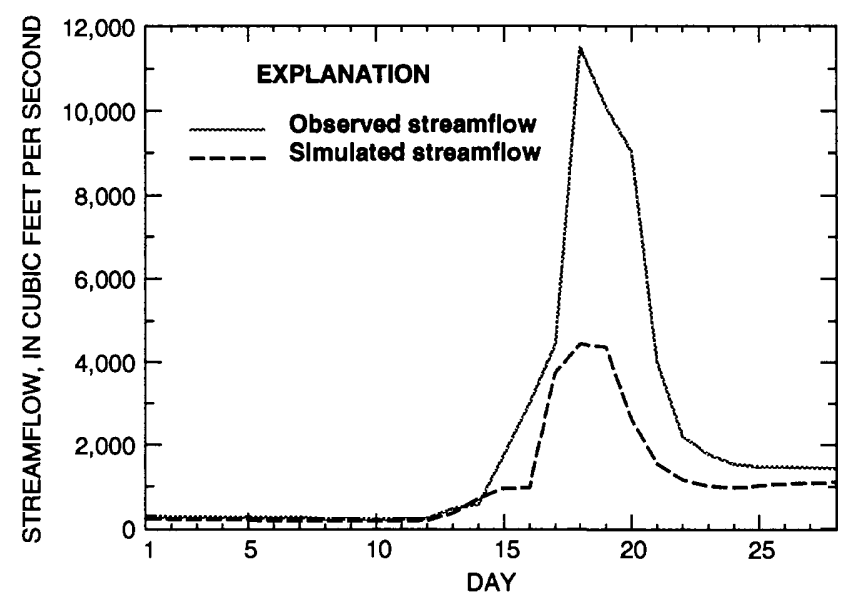

Figure 3. Observed and simulated daily mean streamflow, Carson River near Carson City, Nev. (site 32; pl. 1 and table 1), February 1986, full model.
Because variation in irrigation return flows are largely unknown, a constant percentage of diverted flow was assumed to be returned for each diversion during the entire simulation period without accounting for variability from year to year. In the model, estimates for volume of irrigation return flow were adjusted so that simulated streamflow approacher matching observed streamflow at gaging stations. This series of trial-and-error adjustments relied on the irrigation-efficiency studies as a guideline for the range of percent return flow and were completed durirg periods when contributions from other unmeasured sources were probably minimal. Return-flow pe*centages were adjusted further by manual optimization to minimize differences between observed and sim ilated streamflows by using graphical and statistical conparisons. Thus the return-flow percentages were uset as a calibration parameter. Final percentage values are in table 4.

\section{Comparison of Observed and Simulated Streamflow}

\section{Daily Mean Streamflow}

The ability of the model to simulate daily mean streamflow was tested by comparing observed and simulated flow at five USGS gaging stations for the full model and submodels (table 5). A comparison is shown in figure 4. Two statistical values were computed for the daily mean streamflow. The mean absolute error is the average of differences between simulated and observed streamflows, disregarding whether the difference was positive or negative. (A mean ab olute difference of 16 percent means that the simulated monthly mean streamflow differs, on average, 16 percent from the corresponding observed val ies.) The bias is the algebraic average of differences between simulated and observed streamflows taking into account the sign of individual differences. A positive bias means that the model, in general, c verestimates streamflow; conversely, a negative bias means the model underestimates streamflow. (See footnote in table 5 for formal mathematical defir itions of the statistical measures.) 


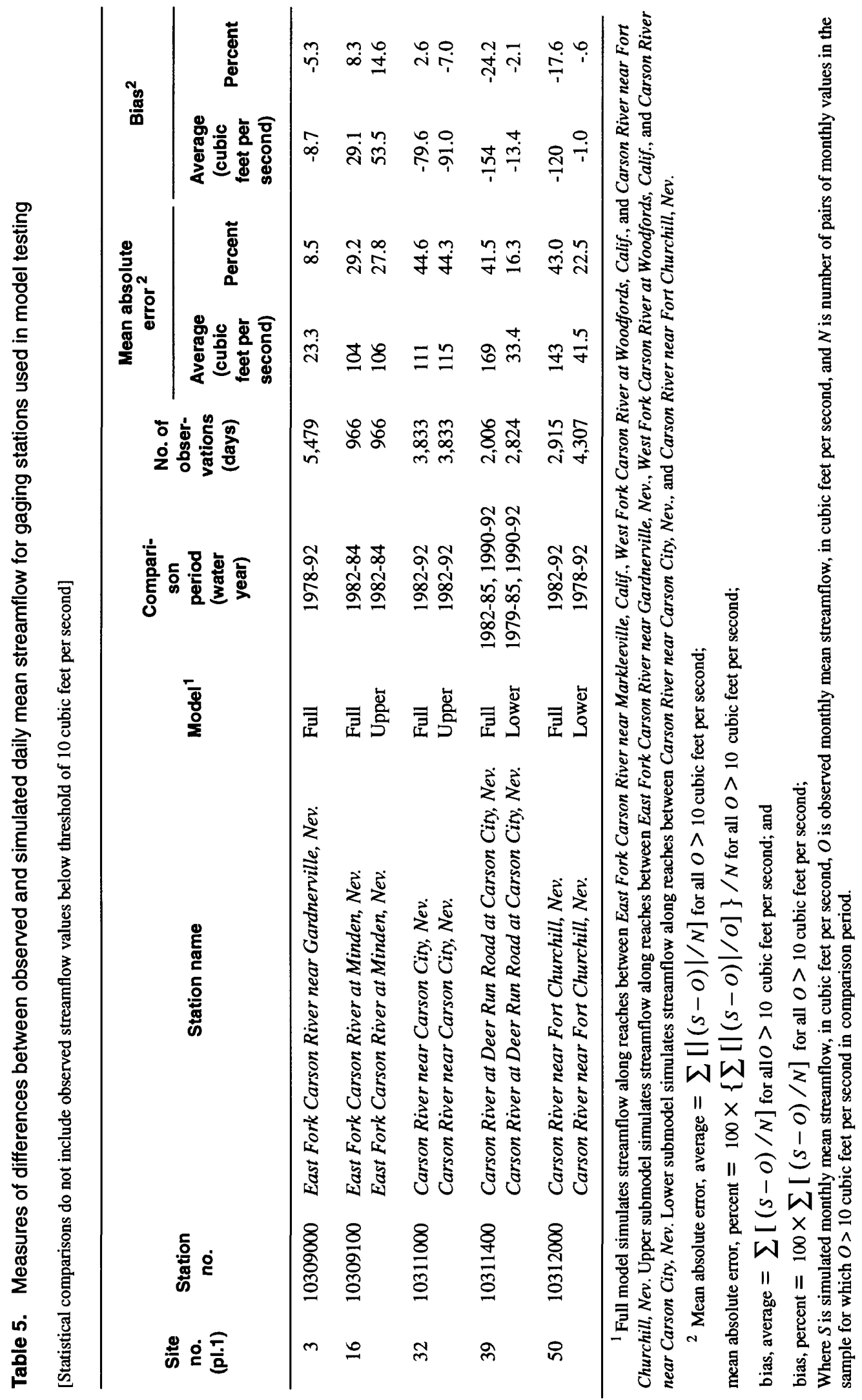




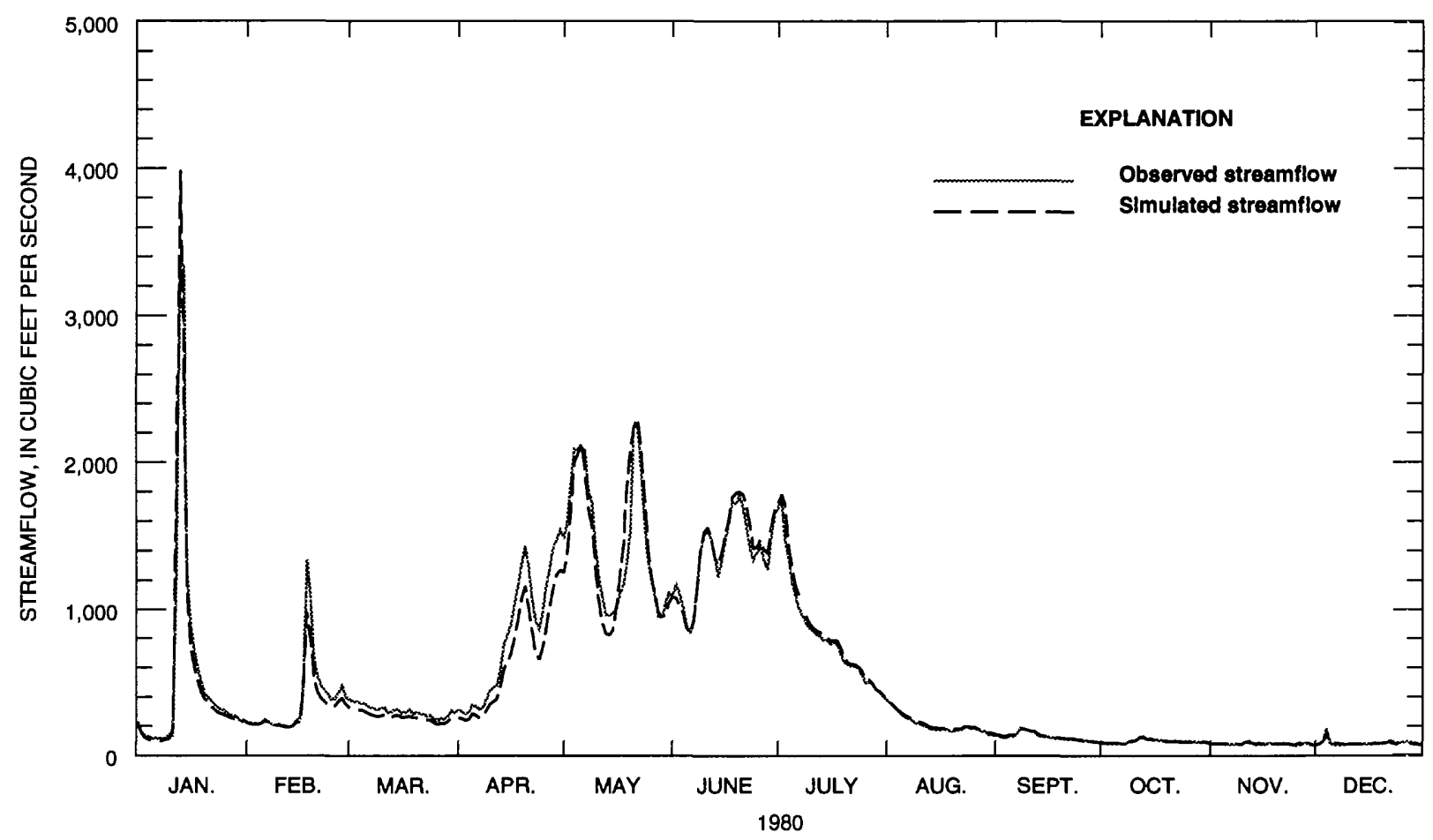

Figure 4. Observed and simulated daily mean streamflow, East Fork Carson River near Gardnerville, Nev. (site 3; pl. 1 and table 1), January through December 1980, full model.

The statistical comparisons used to evaluate the model do not include streamflow values less than $10 \mathrm{ft}^{3} / \mathrm{s}$. The justification for using this threshold is the uncertainty in estimating some components of the hydrologic system, such as ground-water inflow or irrigation return flow, and inaccuracies of gaging-station data. Regulatory effects of reservoirs on the Carson River upstream from Lahontan Reservoir are negligible; streamflow is not supplemented by releases from upstream reservoirs. In dry years, streamflow often ceases at several locations due to extensive irrigation (fig. 5). When observed streamflow approaches zero, all statistical comparisons (expressed as a percentage of the observed values) can be misleading. For example, if the simulated streamflow is $1.0 \mathrm{ft}^{3} / \mathrm{s}$ and the observed streamflow is $0.1 \mathrm{ft}^{3} / \mathrm{s}$, the mean absolute error is 900 percent, which seems large compared to the difference between the two, $0.9 \mathrm{ft}^{3} / \mathrm{s}$.

\section{Model Limitations and Model Improvements}

The general differences between simulated and observed streamflows can be described by a statistical analysis of the differences and by comparing hydrographs of observed and simulated streamflow.
A discussion of the differences between observed and simulated streamflow in the following sections describes (1) general sources of differences, (2) individual sources of differences, (3) model limitations, and (4) suggestions for improved model simulations.

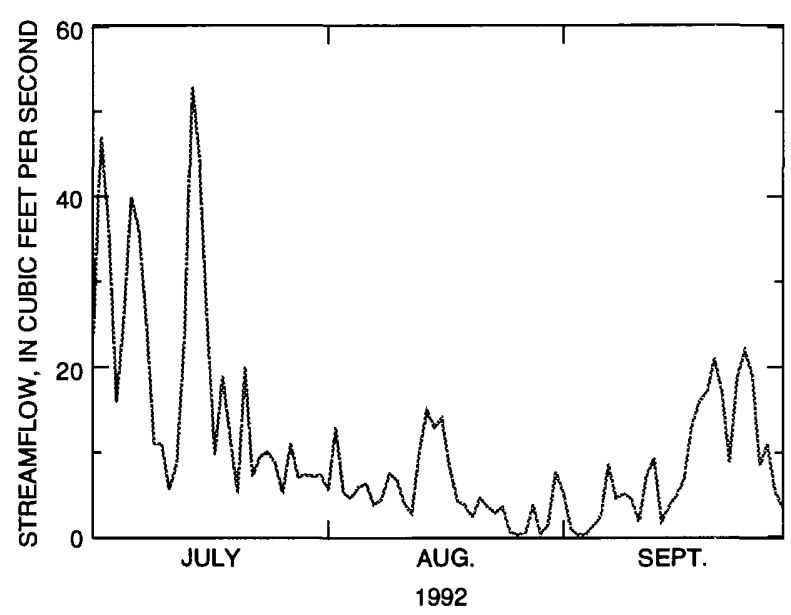

Figure 5. Observed daily mean streamflow, Carson River near Carson City, Nev. (site 32; pl. 1 and table 1), July through September 1992, full model. 


\section{General Differences}

The magnitude of the general differences is assessed by reviewing the model simulations taking into account the accuracy of the observed streamflow data used in the flow-routing model. Although the statistics used to determine accuracy of data from gaging stations are not the same as those used to analyze streamflow simulations in this report, the percent differences can provide general trends in the differences. These general trends describe differences between full model and submodel, upstream and downstream direction, and flows over time.

The measures of differences between observed and simulated daily mean streamflow (table 5) were markedly greater for the full model than for the lower submodel for all statistics; the mean absolute error was $143 \mathrm{ft}^{3} / \mathrm{s}$ for the full model and $41.5 \mathrm{ft}^{3} / \mathrm{s}$ for the submodel at the gaging station near Fort Churchill. The likely reason why the lower submodel simulates flow better than the full model at downstream stations is that the lower submodel does not incorporate the cumulative simulation differences associated with upstream Carson River segments. When an inflow or outflow is not adequately described, either because of an inaccurate time series or the lack of a necessary time series, differences between observed and simulated streamflow result. These differences originate where the inflow or outflow is inadequately described, and the error continues to accumulate as flow is routed downstream by the model. For example, if unrecorded irrigation return flow enters the Carson River, and is not estimated for input to the model by a time series, then the model will underestimate Carson River streamflow beginning just downstream from that return. This underestimation will result in a difference between observed and simulated streamflow equivalent to the amount of irrigation return flow that is not included in the time-series data. The model will continue to underestimate streamflow at successive downstream gaging stations. Similarly, inadequate flow data can create differences between observed and simulated streamflow, and these differences are added to the differences introduced upstream. For this report, these cumulative differences are defined as uncertainties that increase as the length of reach modeled increases. The cumulative simulation differences are greater along the $94.5 \mathrm{mi}$ of the Carson River to the gaging station near Fort Churchill (full model) than along the $39.6 \mathrm{mi}$ of the Carson River to the gaging station near Fort Churchill (lower submodel). Similar differences in full model and submodel cumulative differences were found for the gaging station at Deer Run Road. However, no significant differences in the mean absolute error were found between full and upper submodel simulations at the gaging stations at Minden and Carson City. The accumulation of simulation differences is about the same along the $26.0 \mathrm{mi}$ of the Carson River to the gaging station at Minden in the full model as along the $14.9 \mathrm{mi}$ of the Carson River to the gaging station at Minden in the lower submodel.

The percent bias of the differences between observed and simulated daily mean streamflows can be compared to the accuracy of data from USGS gaging-stations. For example, the percent bias at the gaging station on the East Fork at Minden (table 5) indicates that the full model, on average, overestimates flow by 8.3 percent. The average accuracy of data from this USGS gaging station was poor (defined as greater than 15 percent difference from the true streamflow); therefore, the model simulates daily streamflow witl in the accuracy of the observed data used as input (table 3). Percent bias of the full model for daily simulations of flow at the gaging stations near Gardnerville, Minden, and Carson City is similar to rated accuracy of the observed data; this also is true for the upper submodel at the Minden and Carson City gaging stations and for the lower submodel at the Deer Run Road and Fort Churchill gaging stations.

The average bias for daily mean streamflow (table 5) for the full model from the most upstream to the most downstream gaging station indicates a negative bias at the downstream gaging stations. Tre only exception is the gaging station at Minden, whirh has only 3 years of data for comparison. The negative bias indicates that the model is consistently underestimating simulated streamflow, which is probably due to the underestimation of tributary inflow in the model. Similarly, a tendency toward negative bias at the most downstream stations is shown by the comparison of bias for the submodels.

\section{Individual Sources of Differences}

To determine whether differences between simulated and observed streamflows resulted from inadequate data characterizing inflow and outflow from the Carson River, the individual components of the hydrologic system were further examined. The following sections (1) illustrate the close matcl 
of hydrographs of observed and simulated data when the hydrologic system is adequately described; (2) describe specific differences resulting from differences in selected components of the hydrologic system; and (3) provide a sensitivity analysis of the relative effects of selected components of the hydrologic system on model simulations.

Differences between observed and simulated streamflows cannot always be attributed to time-series data representing a single component of the hydrologic system. Many components must be estimatedungaged ground-water inflow, tributary inflow, and irrigation return flow-as a result, those estimates can accumulate into large simulation errors. The source of the differences is often difficult to isolate. The following are examples of the most probable source of differences. For each example, however, other components may be contributing to the differences.

When observed and simulated hydrographs closely match, the inflow to and outflow from the Carson River are probably adequately represented by the models. For example, a graphical comparison of daily simulated and observed streamflow for the East Fork near Gardnerville for 1990 (fig. 6) shows small differences. During this period in 1990 (a below average runoff year), ungaged tributary inflow, groundwater inflow, and irrigation usage upstream from this station were small (197 acres are irrigated near Rryant Creek according to the Alpine Decree [U.S. Dis'rict Court, 1980, p. 20-21]). These three component: of inflow and diversion, although not estimated, aproar to be insignificant. This illustrates that the model is useful for daily flow-routing even though some of the smaller components of the hydrologic system are not included.

The small differences between observed and simulated streamflow at the Gardnerville gaging station (table 5) can be attributed to the minimal irrigation upstream from the station, which was estimated as zero in the model. Ground-water contributions to streamflow in the upstream basin were estimated to be zero and the estimation of the tributary inflow' component of the streamflow from ungaged basins may be under estimated. These three components may account for the small negative bias.

The East Fork upstream from Minden is characterized by heavy irrigation. The FWM has seven gaging stations on major irrigation ditches upstream from Minden, but the minor irrigation ditches are not gaged. Return flows are not measured in this area. Differences between observed and simulated

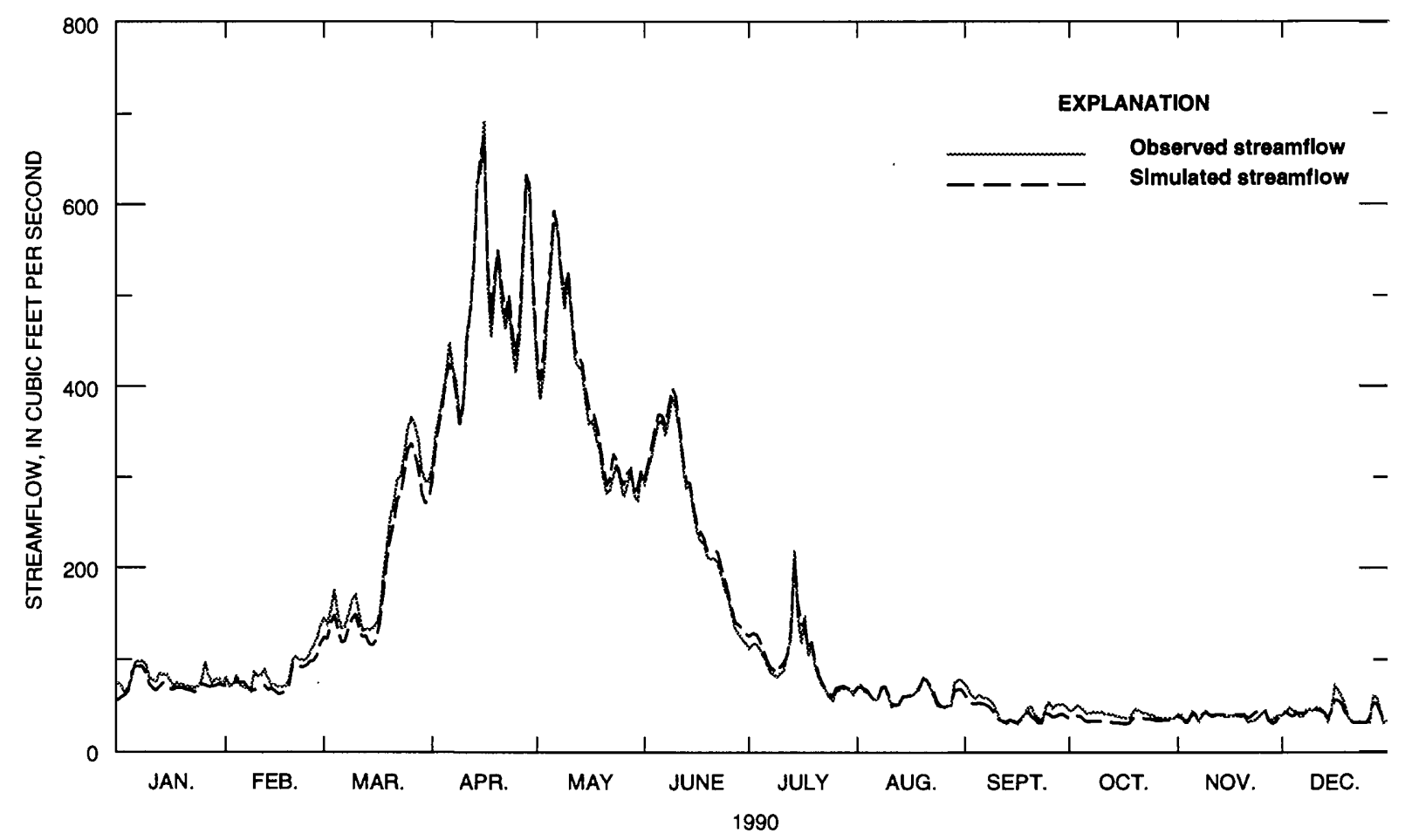

Figure 6. Observed and simulated daily mean streamflow, East Fork Carson River near Gardnerville, Nev. (site 3; pl. 1 and table 1), January through December 1990, full model. 
streamflow at the Minden gaging station (table 5) occur because data on the irrigation diversion and return flow are incomplete. As shown in the previous section, differences between the full model and upper submodel simulations at the gaging station at Minden are insignificant. The two models contain identical input and output flow data, so no additional error is introduced to the full model.

The differences between observed and simulated streamflow at Carson River near Carson City (table 5) are relatively small considering that this station is downstream from the mostly undefined and complex system of channels, reservoirs, diversions, and return flows in Carson Valley. The differences at this station are attributed to lack of data on irrigation diversion, irrigation return, under estimated tributary inflows, and unknown ground-water inflow.

Differences between observed and simulated streamflow in the full model are high at the most downstream gaging station near Fort Churchill (fig. 7). The reach between Carson City gaging station and the Fort Churchill gaging station has several ungaged irrigation ditch diversions, ungaged returns, and unknown ground-water inflow. The comparison of full model and lower submodel results show that the differences between observed and simulated streamflow for the full model can be attributed to cumulative differenc?s incorporated into the model upstream from the Cars $n$ City gaging station. The larger submodel differencer reflect much smaller errors than the full model for this reach.

Estimated flow data are another source of inaccurate time-series data, and the accuracy of the estimates commonly is not known. Flow data were estimated to provide as many inflow and outflow time-series data to the model as possible. The estimated time-series data are not as accurate as data from gaging-station records, but they introduce less error into the model than would occur by not accounting for the flow. Following are four examples of how inaccurate estimated flow data may cause individual differences; sensitivity analysis of the examples indicates the relative magnitude of each component. The following discussion shows the sensitivity analysis of (1) estimated ungaged-tributery streamflow, (2) estimated irrigation-diversion flow, (3) estimated irrigation-return flow, and (4) estimated ground-water inflow.

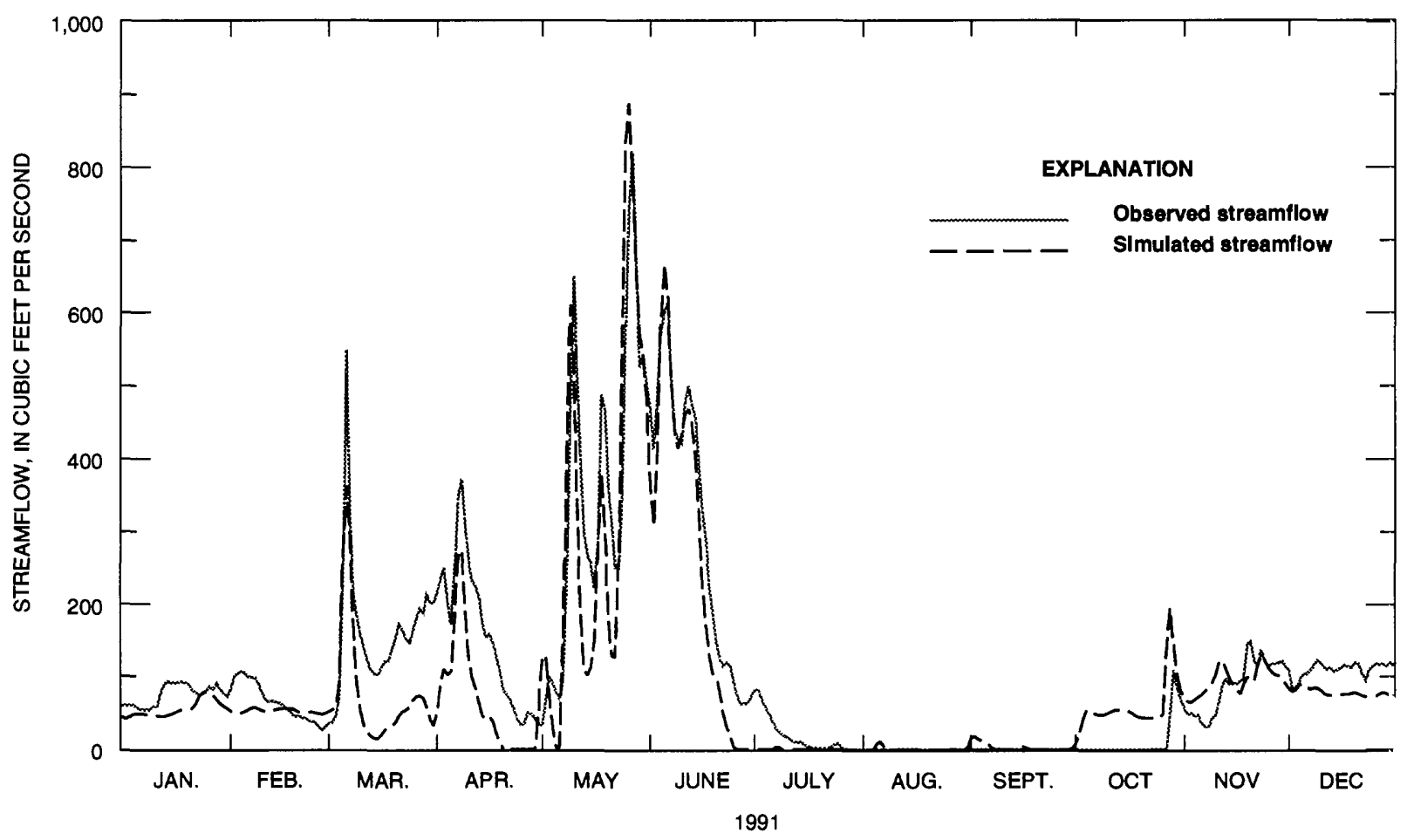

Figure 7. Observed and simulated daily mean streamflow, Carson River near Fort Churchill, Nev. (site 50; pl. 1 and table 1), January through December 1991, full model. 
Estimated ungaged tributary streamflow from the mountainous reaches of the East Fork define intervening streamflow. As described in the "Estimated Flow" section, ungaged tributary streamflow was estimated for the East Fork only for water years 1978-82 and ungaged tributary inflow from reaches on the West Fork and mainstem Carson River downstream from Carson Valley were not estimated. A sensitivity analysis of the ungaged tributary inflow (table 6) for the East Fork gaging station near Gardnerville for this period shows that the mean absolute error of the differences between all daily observed and simulated streamflow ranged from 7.0 to 7.2 percent for half and double the estimated ungaged tributary inflow, respectively $(0.5$ to 2.0 times). This sensitivity analysis shows that the estimates of ungaged tributary inflow may be in error by 50 to 100 percent and that the ungaged tributary inflow has little effect on the simulation of all daily streamflow. However, an example of ungaged tributary streamflow outside of the period of estimated tributary inflows is shown in a comparison of observed and simulated daily mean streamflow at Carson River near Carson City gaging station for 1986 (fig. 3). The February 1986 snowmelt peak is significantly underestimated because of the lack of estimation of low altitude runoff from tributary inflow from reaches on the mainstem Carson River. This comparison indicates that the model underestimates streamflow during highrunoff periods and the model undersimulates tributary inflow. However during a below average runoff year, the model for 1990 at the Gardnerville gaging station (fig. 6) simulates tributary inflow well. Thus, the estimated ungaged tributary streamflow is not a significant component of the hydrologic system during low-runoff periods but is a significant component during highrunoff periods.

Although irrigation diversion data have been collected at many major irrigation ditches along the Carson River, the gaging-station network does not include every ditch. A sensitivity analysis of the estimated irrigation-diversion flow (table 6) for the East Fork gaging station at Minden indicates that the bias ranged from 13.7 to 0.9 percent, respectively. The sensitivity analysis indicates that a change $(0.5$ to 2.0 times) in the estimated irrigation diversion creates a change in that the statistics (from 0.9 to 13.7 percent bias), and that the estimated irrigation diversion flow is a significant component of the model.

A sensitivity analysis of the estimated irrigation return flow for gaging station on the Carson River near Fort Churchill (table 6) compared simulations with and without estimated irrigation return flow. The analysis for the lower submodel indicates that the bias ranged from -0.6 percent with return flow to -9.9 percent without. The sensitivity analysis indicates that a change in estimated irrigation return flow (with and without) creates a change in the statistics (from -0.6 to -9.9 percent bias), and that the irrigation return flow is a significant component of the model.

In areas where ground-water inflow provides significant streamflow, time-series data for inflow were estimated. A constant value for ground-water inflow (table 2) was used for the period of simulation. Because of uncertainties in components of the hydrologic. system that contribute to ground-water flow, such as irrigation diversions and return flow, the relative magnitude of ground-water inflow is indeterminate and is only roughly estimated in the model. A sensit 'vity analysis of estimated ground-water inflow (table 6) for the Deer Run Road gaging station indicates that the mean absolute error of the differences between daily observed and simulated streamflow rangec' from 241 to $245 \mathrm{ft}^{3} / \mathrm{s}$ for half and double the estimate 1 ground-water inflow, respectively. Similarly, the bias only ranged from -40.3 to -44.8 percent, respect ively. Thus, this sensitivity analysis indicates that when a simplified constant value is used to estimate gro'ındwater inflow, the contribution of ground water dies not significantly affect results of the model.

\section{Model Limitations}

Model limitations were defined based on the investigation of general and individual sources of differences. An unknown amount of Carson River inflow and outflow is not included in the time-series dat 7 used as input and therefore is not represented in the preliminary routing model. The routing model is limited because it cannot simulate these inflows and outflows. The magnitude of simulation differences resulting from model limitations is not fully known.

Between 1986 and 1992, less-than-normal precipitation created severe drought conditions. At all USGS mainstem Carson River gaging statiors, no flow was observed in the late summer during this period. The long-term effect on ground-water levels and ground-water inflow to the Carson River berause of the drought is unknown. These conditions have not been accounted for in model simulations. Similarly, the effects of evapotranspiration losses on daily streamflow is beyond the scope of this report. 


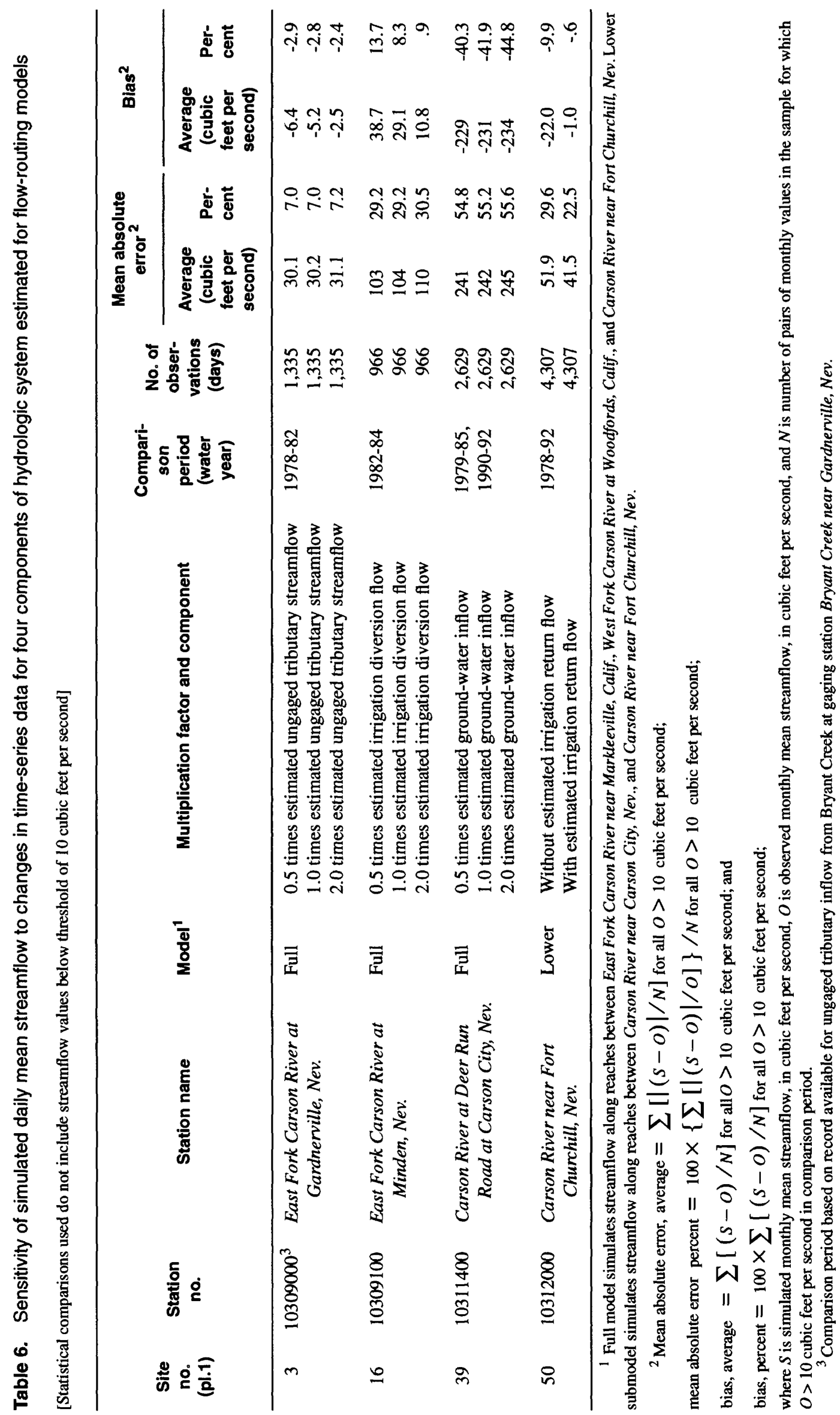


Flow in several ditch diversions along the Carson River was provided by ungaged pumpage of Carson River surface water. This ungaged pumpage was not estimated for this report. Undecreed diversions cannot be estimated using information from the Alpine Decree and therefore were not estimated for this study.

No major changes in irrigation practices have occurred along the Carson River during water years 1978-92 according to Garry Stone (U.S. District Court Water Master, oral commun., 1994). Therefore, the irrigation diversion data for this period should be consistent. However three significant transfers of decreed water rights in the last 10 years have altered patterns of localized surface-water flow in Carson Valley. First, water stored and then planned for release from Mud Lake for municipal water supply will increase streamflow in the late summer in the West Fork and mainstem Carson River in Carson Valley. Second, the conversion of a single large-unit ranch in Carson Valley to many small-unit ranches has altered water usage in those areas. Third, some agricultural water rights being transferred to municipal water supply are not described by the Alpine Decree. Definition of the effect on patterns of localized surface-water flow because of these waterrights transfers is beyond the scope of this report.

\section{Model improvements}

The modeling for this progress report is preliminary. Results are constrained by current availability and accuracy of hydrologic data. Additional information for testing the current model would better define components of the hydrologic system. Data from gaging stations at additional sites along the Carson River and its major tributaries would provide consistent data to support the model. Additional lowflow investigations would quantify ground-water inflow near Gardnerville. Additional tributary streamflow data would help in estimating the contributions of ungaged tributaries from the mountainous reaches of the Eastern Sierra to the East Fork and West Fork during normal runoff and from adjacent areas of the Carson River near Carson City during high spring runoff. Additional flow data from several sites in Carson Valley could be added to the streamflow network to define some of ungaged irrigation diversion and return flow. Gaging stations on several irrigation ditches have been added to the streamflow network in Carson Valley to document patterns of localized surface-water flow caused by the three significant transfers of decreed water rights. A gaging station at the outlet from Mud Lake, operated by private consultants, also has been added.

The irrigation efficiency varied with location and time of the year as shown on three ranches in the Carson Valley in 1974-75 (Guitjens and Mahanrah, 1975, 1977). Although this model has simplified the estimation of irrigation return flow by using a constant percentage (table 4), HSPF could vary the percentage of the return flow, if supported by observed data. for different times in the irrigation season. Also, additional low-flow investigations of streamflow measurements at currently ungaged miscellaneous sites could improve the accuracy of estimating irrigation return flow.

Using methods similar to those described ty Blodgett and others (1984), gaging-station data could be used to develop regression relations to determine streamflow for ungaged tributary basins for different streamflow regimes or times of the year. Regression relations could be developed between gaged mainchannel flow and gaged tributary flow. However, inadequate estimates may result if (1) the gaging: stations do not have similar hydrologic and physiographic characteristics, and (2) perennial springflows upstream from gaging stations are not representative of streamflow in the entire drainage areas.

The long-term effect of drought on ground-water levels and inflow to the Carson River is unknown. A ground-water model similar to Maurer's (1986) and Maurer and Peltz's (1994) could be added as a module to the modeling system to provide better estimates of the annual or monthly contributions from ground-water inflow. A ground-water network operated by the USGS for Douglas County in Carson Valley may provide information regarding long-term ground-water levels in Carson Valley. Also, additional low-flow and potentiometric-surface investigations along the Carson River could improve the accuracy of estirnating ground-water inflow.

Simulation of streamflow over long distances between Carson River gaging stations is difficult. because some components contributing to the hy'drologic system are not know. For example, the distance between the gaging stations at Deer Run Road an 1 near Fort Churchill (pl. 1) is $32.6 \mathrm{mi}$. An additional gaging station along this distance would help define the magnitude of irrigation diversions, ground-water inf ow, and irrigation return flow affecting streamflow on the Carson River along this reach. 
Models could be improved by including average annual phreatophyte transpiration and evaporative losses (evapotranspiration) along the Carson River, as estimated by Glancy and Katzer (1975, p. 62-64). Data on evaporation, precipitation, locations of phreatophytes, and phreatophyte uptake collected by other agencies could help define the magnitude of evapotranspiration to be added to future model simulations.

Lahontan Reservoir stores the streamflow of the Carson River below Fort Churchill, plus some water diverted from the Truckee River via the Truckee Canal. However, with the inflow to the reservoir, a reservoir stage/volume relation, and reservoir evaporation data, HSPF could simulate the stage of Lahontan Reservoir for water management.

The inflow to Lahontan Reservoir from the Truckee Canal consists of the diversion at Derby Dam on the Truckee River minus spills, seepage losses, and deliveries to the Truckee Division laterals along the Truckee Canal. Modeling of Truckee Canal flow is beyond the scope of this report. However, with data on the inflow to the canal, lateral diversion data, and hydraulic data, HSPF could simulate flow in the Truckee Canal for water management.

\section{SUMMARY}

Water-related conflicts are long-standing among various economic, political, ecological and institutional interests in the Truckee and Carson River Basins in Nevada and California. Such interests involve a wide range of alternatives for planning, allocating and managing the water resources and for operating the various reservoirs and diversion systems. Public Law 101-618, the Truckee-Carson-Pyramid Lake Water Rights Settlement Act of 1990, was legislated to develop operating criteria to budget interstate allocation and water demands for municipal use, irrigation, fish and wildlife, and recreation as well as to meet water-quality criteria for these uses. The Truckee-Carson Program of the USGS has been asked to assist the Department of Interior in implementing Public L.aw 101-618 by (1) consolidating a number of multi-agency water-monitoring records into a long-term data base to provide consistent and reliable data to support modeling activities in both the Truckee and Carson River Basins and the Truckee Canal, and (2) developing and supporting modular hydrologic and hydraulic models using daily data for the Truckee and Carson River system and Truckee Canal. These models also will be coupled with an operations-and-management model. This progress report focuses on part of the efforts of the Truckee-Carson Program to develop and apply a physically based flow-routing model for the mainstem Carson River to simulate daily streamflcw.

The purpose of this progress report is (1) to describe the data, including a description of the methods used to estimate ungaged flows, and reach segmentation used in the construction of a daily flow-rout:ng model that incorporates hydraulic characteristics of the Carson River, (2) to describe models that test the hydrologic and hydraulic characterization of the Carson River by comparing observed and simulated streamflow, and (3) to discuss the differences between observed and simulated streamflows and the limitations of the model. No previous study of the Carson River has incorporated multi-agency daily streamf ow data into one comprehensive data base and developed a physically based flow-routing model calibrated with the daily data. The report models streamflow for water years 1978-92 from the mainstem East Fork Carson River near Markleeville and mainstem West Fork Carson River at Woodfords down the Carson River to Fort Churchill near Lahontan Reservoir.

The physically based flow-routing model, constructed with the Hydrological Simulation Program-FORTRAN, was used to simulate daily flow. Where daily streamflow data for the mainstem rive", tributaries, and irrigation ditches were unavailable or incomplete, hydrologic techniques were used to estimate some flow data. Cross-sectional survey data required for determining hydraulic characteristics for river reaches used in the model were compiled from field surveys and previous studies. The Channel Geometry Analysis Program was used to compute the hydraulic properties of reaches and provided graph $:$ al representations of stage-discharge relations and plits of cross sections. For modeling purposes, the Cars on River-from the East Fork gaging station near Markleeville and West Fork gaging station at Woodfords to the mainstem Carson River gaging station at Fort Churchill-was divided into 6 segments and 48 individual stream reaches. Each segment was divided into several reaches, generally 2 to $3 \mathrm{mi}$ long.

The flow-routing model was tested to determine if differences between observed and simulated streamflow resulted from inadequate data describing the hydraulic characteristics of the Carson River. Model 
testing demonstrated that channel shape, roughness, slope, and length are adequately represented in the models for a range of flow regimes. The differences between observed and simulated streamflow mostly result from inadequate data characterizing inflow to and outflow from the Carson River. Because irrigation return flows are largely unknown, irrigation return flow percentages were used as a calibration parameter to minimize differences between observed and simulated streamflows. Observed and simulated streamflow for daily intervals were compared for the full modeled length of the Carson River and for two major subreaches modeled with more detailed input data using hydrographs and statistics.

General sources of differences between simulated and observed streamflow were described. Because HSPF uses the observed streamflow data as model input, the simulations can only be expected to be within the average percent accuracy of the observed streamflow recorded at USGS gaging stations. For daily time intervals, the full model simulated streamflow near the Gardnerville, Minden, and Carson City gaging stations are within the recording accuracy of those stations. The submodel simulations at the Minden, Carson City, Deer Run Road, and Fort Churchill gaging stations also are within the accuracy of the observed streamflow. For daily mean streamflow, the full model and submodel simulations near the Minden and Carson City gaging stations are about the same. At gaging stations farther downstream, however, the streamflow simulations by the submodel are more accurate than those by the full model. This difference is because in the full model, the differences between observed and simulated streamflow accumulate as the model routes flow downstream.

Sources of differences between observed and simulated streamflow are discussed for four gaging stations. A sensitivity analysis was made to determine which components of the hydrologic system were significant in the model. The estimated ungaged tril utary streamflow is not a significant component of the model during low runoff, but is significant during high runoffs. The sensitivity analysis indicates that a change in the estimated irrigation diversion and estimated return flow creates a noticeable change in the statistics. Estimated ground-water inflow when a simplified constant value is used, on the other hand, is not a significant component of the flow-routing model.

The modeling for this study is preliminary. Results of the model are constrained by the curront availability and accuracy of observed hydrologic data. Several Carson River inflows and outflows are $r$ t described by time-series data and, therefore, are not represented in this flow-routing model. Data could be incorporated into the model from gaging stations recording these unrepresented flows from the major tributaries, diversions, and returns, as well as from sites along the Carson River. Expansion of the datacollection network would provide additional information for testing the current model and for future modifications to better define components of the. hydrologic system. 


\section{REFERENCES CITED}

August, M.H., Jacoboni, J.M., Jeton, A.E., Parker, R.S., Pupacko, Alex, Ruddy, B.C., Smith, J.L., and Redmond, K.T., 1992, Hydrologic and climatic data bases used to assess potential effects of climate change on water resources of American River, Carson River, and Truckee River Basins, California-Nevada, and of Gunnison River Basin, Colorado: U.S. Geological Survey Open-File Report 92-627, 72 p.

Berris, S.N., 1995, Conceptualization and simulation of runoff generation from rainfall for three basins in Thurston County, Washington: U.S. Geological Survey Water-Resources Investigations Report 94-4038.

Berris, S.N., in press, Daily-flow routing simulations for the Truckee River, California and Nevada: U.S. Geological Survey Water-Resources Investigations Report 964097.

Bicknell, B.R., Imhoff, J.C., Kittle, J.L., Donigan, A.S., and Johanson, R.C., 1993, Hydrological simulation program-FORTRAN: User's manual 10 EPA/600/R-93/174, Environmental Research Laboratory, $660 \mathrm{p}$.

Blodgett, J.C., Oltmann, R.N., and Poeschel, K.R., 1984, Estimation of streamflow for selected sites on the Carson and Truckee Rivers in California and Nevada, 1944-80: U.S. Geological Survey Water-Resources Investigations Report 84-4058, 223 p.

Brown, W.M., III, Nowlin, J.O., Smith, L.H., and Flint, M.R., 1986, River-quality assessment of the Truckee and Carson River system, California and NevadaHydrologic characteristics: U.S. Geological Survey Open-File Report 84-576, 201 p.

California Department of Water Resources, 1991, Carson River atlas: Sacramento, $133 \mathrm{p}$.

Carson Valley Conservation District, Douglas County, Nevada, Carson Valley Aerial Mapping Project, 1988, scale 1:400, contour interval 5 feet: aerial photography by Genge Aerial Surveys, Sacramento, Calif., image date 6-1-77, 51 sheets.

Cartier, K.D., Peltz, L.A., and Smith, J.L., 1994, Development and documentation of spatial data bases for the Lake Tahoe Basin, California and Nevada: U.S. Geological Survey Water-Resources Investigations Report 93-4182, 65 p.

Clyde-Criddle-Woodward, Inc., 1971, Final report on wateruse improvement study of the Truckee-Carson River Basin: Salt Lake City, Clyde-Criddle-Woodward, Inc., $111 \mathrm{p}$

Cobb, E.D., Olson, A.F., Moosburner, Otto, and Pupacko, Alex, 1990, Review of selected water-management models and results of simulations for the TruckeeCarson Rivers system, California and Nevada: U.S. Geological Survey Open-File Report 90-393, 40 p.
Dangberg, Grace, 1975, Conflict on the Carson-A study of water litigation in western Nevada: Carson Valley Historical Society, Minden, Nev., 467 p.

Dinicola, R.S., 1990, Characterization and simulation of rainfall-runoff relations for headwater basins in western King and Snohomish Counties, Washingtor: U.S. Geological Survey Water-Resources Investigations Report 89-4052, $52 \mathrm{p}$.

Duell, L.F.W., Jr., 1992, Use of regression models to estimate effects of climate change on seasonal streamflow in the American and Carson River Basins, California-Nevada, in Hermann, R., ed., Managing Water Resources during Global Change: American Water Resources Association, Reno, November 19ऽ2, Nevada, Proceedings, p. 731-740.

Federal Emergency Management Agency, 1986, Flood insurance study, unincorporated areas of Douglas County, Nevada, August 1986: 23 p., 16 plates. 1989, Flood insurance study, city of Carson City, Nevada, March 1989: 31 p., 30 plates. 1992a, Flood insurance study, Douglas County, Nevada, and incorporated areas, September 1992: 25 p., 18 plates.

1992b, Flood insurance study, Lyon County, Neva ta, unincorporated areas, September 1992: 34 p., 30 pla ${ }^{+}$es.

Glancy, P.A., and Katzer, T.L., 1975, Water-resources appraisal of the Carson River Basin, western Nevada: Nevada Division of Water Resources, Reconnaissarce Report 59, $126 \mathrm{p}$.

Guitjens, J.C., and Mahannah, C.N., 1975, Upper Carsor River water study, water year 1974: University of Nevada, Reno, Agricultural Experiment Station Rep rrt $107,34 \mathrm{p}$.

1977, Upper Carson River water study, water year 1975: University of Nevada, Reno, Agricultural Experiment Station Report 120, 32 p.

Jeton, A.E., and Smith, J.L., 1993, Development of watershed models for two Sierra Nevada basins using a geographic information system, in Harlin, J.M., and Lanfear, K.J., eds., Geographic Information System and Water Resources: American Water Resources Association, Mobile, Ala., March 1993, Proceeding , p. 251-258.

Kennedy/Jenks Consultants, 1991, Upper Carson River MODSIM river model: Reno, Carson Water Subconservancy District, Report No. 877029.07, 354 p.

Langbein, W.B., and Iseri, K.T., 1960, General introduction and hydrologic definitions: U.S. Geological Survey Water-Supply Paper 1541-A, 29 p.

Lumb, A.M., Kittle, J.L., and Flynn, K.M.,1990, Users manual for ANNIE, a computer program for interact ve hydrologic analyses and data management: U.S. Geological Survey Water-Resources Investigations Report 89-4080, 236 p. 
Maurer, D.K., 1986, Geohydrology and simulated response to ground-water pumpage in Carson Valley, a riverdominated basin in Douglas County, Nevada, and Alpine County, California: U.S. Geological Survey Water-Resources Investigations Report 86-4328, 109 p.

Maurer, D.K., and Peltz, L.A., 1994, Potential for, and possible effects of, artificial recharge in Carson Valley, Douglas County, Nevada: U.S. Geological Survey Water Resources Investigations Report 94-4126, 4 sheets.

Nevada Division of Environmental Protection, 1982, Water quality management (208) plan for the Carson River Basin, Nevada: Nevada Department of Conservation and Natural Resources, 303 p.

Nowlin, J.O., Brown, W.M., III, Smith, L.H., and Hoffman, R.J., 1980, Planning and design of studies for riverquality assessment in the Truckee and Carson River Basins, California and Nevada: U.S. Geological Survey Open-File Report 80-435, 75 p.

Piper, A.M., 1969, A water budget of the Carson Valley, Nevada: U.S. Geological Survey Professional Paper 417-F, 8 p.

Pupacko, Alex, 1993, Variations in northern Sierra Nevada streamflow-Implications of climate change: Water Resources Bulletin, v. 29, no. 2, p. 283-290.

Pyramid Lake Task Force, 1971, A study of water rights and their enforcement, Lake Tahoe, Truckee and Carson River Basins: Pyramid Lake Task Force Report, 170 p.

Regan, R.S., and Schaffranek, R.W., 1985, A computer program for analyzing channel geometry: U.S. Geological Survey Water-Resources Investigations Report 85-4335, 49 p.

Smith, S.L., and Reece, B.D., 1995, Watershed characterization for precipitation-runoff modeling system, North Fork American River and East Fork Carson River watershed, California: U.S. Geological Survey Hydrologic Atlas HA-734.
Townley, J.M., 1977, Turn this water into gold-The story of the Newlands Project: Reno, Nevada Historical Society, $160 \mathrm{p}$.

Truckee-Carson-Pyramid Lake Water Rights Settlem $\cdot n t$ Act, 1990, Title II of Public Law 101-618, 104, Stat. $3289,19 \mathrm{p}$.

U.S. Department of the Army, Corps of Engineers, Sacramento District, 1986, Carson River, Douglas County, Nevada, Flood Insurance Study, photogrammetry, scale 1:400, contour interval 5 feet: aerial photography by Topographic Surveys, Inc., Sacramento, Calif., image date October 1986, 12 sheets.

U.S. Department of the Interior, 1935, Truckee River agreement: Approved as to form by Harold L. Ickes, Secretary of the Interior, $20 \mathrm{p}$.

U.S. District Court, Nevada, 1944, The United States of America v. Orr Water Ditch Company, et al.: Final Decree, Equity No. A-3, 88 p.

1980, The United States of America v. Alpine Land and Reservoir Co., et al., Findings of fact, concl isions of law, tabulation and administrative provisions: Final Decree, Civil No. D-183 BRT, 18 p.

U.S. Geological Survey, 1976, 1979-86, 1987a, 1988-95, Water resources data, Nevada, water years 1976. 1978-93: U.S. Geological Survey Water-Data Reports NV-76-1, NV-78-1 to NV-93-1 (published annually).

1987b, National Mapping Program technical instructions-Data user's guide 5, Digital Elevation Models: U.S. Geological Survey, 38 p.

Van Denburgh, A.S., 1973, Mercury in the Carson and Truckee River Basins of Nevada: U.S. Geological Survey Open-File Report 73-352, 15 p.

Worts, G.F., Jr., and Malmberg, G.T., 1966, Hydrolog̣ic appraisal of Eagle Valley, Ormsby County, Nevada: Nevada Department of Conservation and Natural Resources, Water-Resources - Reconnaissance Peport $39,55 \mathrm{p}$. 


\section{GLOSSARY}

Some of the technical terms and acronyms used in this report are defined for convenience of the reader. Statistical terms are defined with respect to the statistical analysis in this report. See Langbein and Iseri (1960) for additional information regarding hydrological terminology.

ANNIE. The time-series data-management system that includes file creation, data management, analysis, and display.

Bias. The algebraic average of differences between simulated and observed values taking into account the sign of individual differences. See footnote at end of table 5 for formal mathematical definition.

CGAP. Channel Geometry Analysis Program.

Cumulative simulation differences. Inadequate flow data can create differences between observed and simulated streamflows at a number of locations; these differences are routed downstream from these locations and are all added to the differences introduced upstream. These cumulative differences are uncertainties that increase as the length of reach model increases.

Daily mean streamflow. The mean streamflow for a given day.

Decreed acreage. Irrigated acreage defined by the Alpine Decree.

DEM. Digital Elevation Model (U.S. Geological Survey, 1987b).

East Fork. East Fork Carson River.

FEMA. Federal Emergency Management Agency.

FTABLE. HSPF block that specifies fixed relations among depth, surface area, volume, and discharge for a river reach.

FWM. U.S District Court Water Master or Federal Water Master.

HSPF. Hydrological Simulation Program - FORTRAN.

HYDR. HSPF block that simulated unsteady flow by representing physical processes using the modified kinematic-wave algorithm.

Hydrographic comparison. A plotted comparison of two or more sets of time-series data showing flow with respect to time.
Irrigation efficiency. Percentage surface-water runoff computed from surface runoff is not necessarily lost for irrigation as irrigators further downstream typically reuse this runoff.

Irrigation return flow. Mostly excess surface-water flow that returns to the mainstem after irrigation and, to a lesser degree, ground-water inflow to the river.

Irrigation season. Usually the 7-month period beginning April 1 and ending October 31 of any given year.

KS. In the daily flow-routing block of HSPF, a variable that is a weighting factor not physically measurable that influences the timing of flow and varies from 0.0 to 1.0 .

Low-flow investigations. Serial, nearly concurrent streamflow measurements along the length of the river to determine areas or points of gain or loss along a river.

Mean absolute error. The average of differences between simulated and observed values streamflow, disregarding whether the difference was positive or negative. See footnote at end of table 5 for formal mathematical definition.

Observed data. The consolidated water data base generated from continuous or intermittent gagingstation data.

RCHRES. HSPF block that simulates processes within a single reach.

Reach. Single zone between two points along the river.

Stockwater diversions. Typically, irrigation diversion outside the irrigation season to provide water for livestock.

UCI. User's Control Input.

USGS. U.S. Geological Survey.

Water balance. An accounting of the inflow to, outflow from, and storage in a hydrologic unit.

Water year. The 12-month period beginning October 1 and ending September 30, and designated by the calendar year in which the water year ends.

West Fork. West Fork Carson River. 
Appendix

- page 41 follows - 
Appendix. Name, size, and description of input files used in Hydrologic Simulation Program for Carson River, California and Nevada ${ }^{1}$

\begin{tabular}{|c|c|c|}
\hline Flle name & $\begin{array}{c}\text { Size } \\
\text { (bytes) }\end{array}$ & Description \\
\hline hspf12.0 & $5,859,268$ & Binary file containing source code for HSPF model version 12.0 . \\
\hline annie2.0 & $3,425,836$ & Binary file containing source code for data management system ANNIE. \\
\hline mast.carson.wdm & $9,625,600$ & Binary file created by ANNIE which contains input and output data sets. \\
\hline carson1.uci & 8,321 & UCI file for segment 1 , full model. \\
\hline carson2.uci & 17,906 & UCI file for segment 2 , full model. \\
\hline carson4.uci & 9,118 & UCI file for segment 4 , full model. \\
\hline carson5.uci & 25,449 & UCI file for segment 5 , full model. \\
\hline carson6.uci & 12,516 & UCI file for segment 6 , full model. \\
\hline carson7.uci & 31,596 & UCI file for segment 7 , full model. \\
\hline carson2p.uci & 14,490 & UCI file for segment 2 , submodel. \\
\hline carson6p.uci & 12,500 & UCI file for segment 6 , submodel. \\
\hline carson7p.uci & 31,577 & UCI file for segment 7 , submodel. \\
\hline carson1ut.uci & 11,602 & UCI file for segment 1 , full model, sensitivity analysis for ungaged tributary streamflow. \\
\hline carson2id2.uci & 17,976 & UCI file for segment 2 , full model, sensitivity analysis for estimated irrigation diversion flow. \\
\hline carson2id5.uci & 17,982 & UCI file for segment 2 , full model, sensitivity analysis for estimated irrigation diversion flow. \\
\hline carson7gw2.uci & 31,624 & UCI file for segment 7 , full model, sensitivity analysis for estimated ground-water flows. \\
\hline carson7gw5.uci & 31,582 & UCI file for segment 7 , full model, sensitivity analysis for estimated ground-water flows. \\
\hline carson7prf2.uci & 31,665 & UCI file for segment 7 , submodel, sensitivity analysis for estimated irrigation return flow. \\
\hline
\end{tabular}

\footnotetext{
${ }^{1}$ For more information, contact Public Information Assistant: phone (702) 887-7649; email mfogle@dnvcr1.wr.usgs.gov. The model and results are available in several media, including disks and computer access.
} 